\title{
Literature Review of Socioeconomic and Environmental Impacts of High-Speed Rail in the World
}

\author{
Mohsen Momenitabar ${ }^{1}\left(\mathbb{D}\right.$, Raj Bridgelall $^{1}\left(\mathbb{D}\right.$, Zhila Dehdari Ebrahimi $^{1}\left(\mathbb{D}\right.$ and Mohammad Arani ${ }^{2, *} \mathbb{( D}$ \\ 1 Department of Transportation, Logistics \& Finance, North Dakota State University, Fargo, ND 58105, USA; \\ mohsen.momenitabar@ndsu.edu (M.M.); raj@bridgelall.com (R.B.); zhila.dehdari@ndsu.edu (Z.D.E.) \\ 2 Department of Industrial Engineering, Faculty of Industrial and Mechanical Engineering, \\ Islamic Azad University, Qazvin Branch, Qazvin 34185-14161, Iran \\ * Correspondence: arani.mohammad@gmail.com
}

check for updates

Citation: Momenitabar, M.; Bridgelall, R.; Dehdari Ebrahimi, Z.; Arani, M. Literature Review of Socioeconomic and Environmental Impacts of High-Speed Rail in the World. Sustainability 2021, 13, 12231. https://doi.org/10.3390/su132112231

Academic Editors: Efthimios Bothos, Panagiotis Georgakis, Babis Magoutas and Michiel de Bok

Received: 14 September 2021

Accepted: 27 October 2021

Published: 5 November 2021

Publisher's Note: MDPI stays neutral with regard to jurisdictional claims in published maps and institutional affiliations.

Copyright: (c) 2021 by the authors. Licensee MDPI, Basel, Switzerland. This article is an open access article distributed under the terms and conditions of the Creative Commons Attribution (CC BY) license (https:// creativecommons.org/licenses/by/ $4.0 /)$.

\begin{abstract}
Countries considering high-speed rail (HSR) developments face enormous challenges because of their high deployment cost, environmental obstacles, political opposition, and their potentially adverse effects on society. Nevertheless, HSR services are importantly sustainable that can have positive and transformative effects on the economic growth of a nation. This paper systematically reviews and classifies impact areas of HSR deployments around the world as well as the analytical methods used to evaluate those impacts. We have utilized the scholarly scientific database to find articles in HSR systems. By defining some rules, we select 116 articles between 1997 and March 2020. The approach revealed interesting patterns and trends in space, time, and sentiment of the analyzed impacts on society, the economy, and the environment. The findings can inform decision-making about HSR developments and deployments, and the gaps identified in the literature can propose new research opportunities for future studies.
\end{abstract}

Keywords: socioeconomic impact; environmental impact; sentiment analysis; political lobbying; sustainability; literature review

\section{Introduction}

High-speed rail (HSR) is categorized as a transport mode that uses a combination of specialized rolling stock and dedicated tracks to transfer passengers between origins and destinations. HSR runs significantly faster and smoother than traditional trains. The first HSR systems appeared in Tokyo, Japan in 1964, known as bullet trains that connected cities with the aim of travel time savings and the mitigation of capacity constraints on existing railways. France was the next country to make high-speed rail available to the public in 1981-the system connected Paris and Lyon with speeds up to $124 \mathrm{mph}$. Today, the French high-speed rail network grew to more than $2800 \mathrm{~km}$ with the Lignes à Grande Vitesse (LGV) allowing speeds of up to $200 \mathrm{mph}$ [1].

Some of the acknowledged benefits of HSR are shorter travel time across long distances, lower transportation costs, reduced fuel consumption, lower highway, and air traffic congestion, rising land values, and economic development in large and small communities [2]. According to a study by Chinese and U.S. economists, extending bullet trains can increase the value of the real estate, improve the quality of life, reduce air pollution, reduce traffic congestion, and provide more travel options for crowded cities, especially in the developing world [3]. The Chinese study is based on the nation's high-speed rail network, but the researcher's project is that the benefits experienced there would be the same for California's proposed HSR system. A study coordinated by Tsinghua University and the University of California found that bullet train systems connecting China's largest cities to nearby smaller cities have made those cities more attractive for workers, alleviated traffic congestion, and reduced pollution in megacities [4]. 
The deployment of HSR in the United States will provide Americans with more transportation choices. However, HSR deployment is one of the most expensive and politically charged undertakings of any nation. Therefore, decision-makers would benefit from an updated and comprehensive review of HSR deployment impacts. The most recent review of HSR deployments around the world is more than a decade old [5]. In that review, the authors focused on the various development and operating cost models of HSR deployments through 2006. There were later studies about HSR impacts on society, but they focused only on local regions. For example, a recent study of bullet train systems in China found they reduced traffic congestion, decreased air pollution, attracted workers to smaller connecting cities, and increased the value of nearby real estate [3,4]. Even with so many external benefits, the United States has only recently approved HSR developments in a few large cities [6].

Researchers and policymakers can benefit from an updated literature review that synthesizes and classifies the body of knowledge on HSR impacts on society to guide decision-making for expanding deployments. Hence, the main goal of this study is to offer a comprehensive review of worldwide HSR deployments. The objective is to classify the impact areas, classify the methods used to understand the impacts, explore patterns in the publication of those categories, and identify gaps for future exploration. The contributions of this work are:

Development of a comprehensive and systematic literature review of HSR developments with a focus on societal and economic impacts to benefit future research, policymaking, and decision-making (Section 2).

Mapping of the factors and measures assessed in every article studied (Section 3).

Classification of impact areas and analysis methods to visualize their publication patterns by time, sentiment, and region (Section 3).

Assessment of the advantages and disadvantages of each method (Section 4).

Description of insights from observed patterns of publications (Section 4).

Assessment of possible gaps that require future work (Section 5).

Other than the sections mentioned above, the rest of the paper is structured as follows. Section 2 discusses the methodology of article selection, impact area classification, analysis technique classification, and bivariate frequency distributions to reveal patterns. Section 3 covers the results of the applied methodology and Section 4 discusses their significance. Section 5 concludes the review and suggests future work.

\section{Methodology}

The systematic literature review utilizes a quantitative analysis of article appearances [7-9]. The next subsections describe the databases used for article identification, the article screening and selection criteria, the classification of impact areas from HSR deployments, the classification of analytical methods used to assess those impacts, and the dimensions of the quantitative analysis.

\subsection{Article Identification and Selection}

The search was limited to articles indexed by the three most popular sources of identifying scholarly academic publications, namely the Scopus database, the Google Scholar search engine, and the Web of Science database. The search focused on scholarly academic research with good rigor by excluding books, conference proceedings, and student dissertations. Scopus produced more articles that were relevant to the fields of social, physical, health, and economic sciences $[10,11]$, and from databases of the largest publishers of scholarly academic work such as Routledge, Elsevier, Springer, and Taylor and Francis. Google Scholar has emerged as a contemporary tool to scour the Internet for any source of scholarly academic work that a focused search using Scopus, or the Web of Science may miss.

The search focused on articles published by international peer-reviewed journals in the English language. The initial search revealed that there were more than 2100 arti- 
cles with the exact phrase "High-Speed Rail" in the title, abstract, or keywords. After examining the temporal pattern of relevant and continuous growth in publications, the search narrowed the selection to articles from 1997 to March 2020. This temporal filter reduced the number of articles to just under 2000. Further limiting the subject areas to social sciences, environmental science, business, energy, economics, decision sciences, and multidisciplinary reduced the count to just under 1000 articles. A similar search conducted using the "Advanced search" feature of Google Scholar resulted in more than 2000 articles. Unfortunately, the Google Scholar search did not allow for filters to be defined for article type, subject areas, or to limit the exact phrase to the title, abstract, or keywords. Therefore, the articles needed to be manually cross-referenced to further scrutinize those that did not overlap. Next, a careful review of the title, abstract, and keywords reduced the number of articles to just below 200. Finally, a more careful review of all the articles relative to the research objectives resulted in the selection of 116 articles.

\subsection{Impact Area Classification}

This subsection introduces the classified impact areas, derived by an empirical process. The resulting impact areas were eight broad but distinct categories:

- Energy: consumption and savings for a nation.

- Environment: emissions and air quality.

- Land: allocation impacts on urban sprawl, community severance, and biodiversity.

- Economy: travel behavior, employment, and efficiency effects on local economies.

- Health: quality of life and implications for human health.

- Resilience: vulnerability and resilience of transport systems.

- Policy: implications and analysis of relevant policies.

- Innovations: original approaches to developments and deployments.

The next subsections summarize the significance of each impact area in the studies of HSR development and deployment.

\subsubsection{Energy}

Compared with aviation and automobiles, railroads are eight and four times more energy-efficient, respectively $[6,12,13]$. Although some authors posit that a modal switch to HSR will substantially reduce energy demand [14], others found that the energy demand from HSR is significant [15].

\subsubsection{Environment}

Despite advancements in alternative zero-emission fuels [16], the transport sector continues to increase its carbon dioxide $\left(\mathrm{CO}_{2}\right)$ emissions. Hence, critics argue that HSR will have a relatively low impact on the reduction of $\mathrm{CO}_{2}$ [17]. In contrast, Horvath, and Chester (2012) found that a transition from automotive trips to HSR would positively affect the atmosphere [18]. Yue et al. (2015) found that vehicle operation in China dominated environmental impacts [19]. Several studies concluded that shifting traffic to rail will positively benefit the environment [20-23].

\subsubsection{Land}

The effects of HSR on urban growth include interactions with land use and land price $[24,25]$. Studies associate investments in transport infrastructure with an increase of nearby land value [26]. The theory posits that greater accessibility for people and goods will increase urbanization [27], and the value of the nearby real estate, which in turn will increase property tax revenues [28]. Conversely, there are several adverse consequences such as noise and an increase in crime [28].

\subsubsection{Economy}

HSR promotes competition and economic cohesion [29]. The convergence of HSR with traditional railways can accelerate urban growth [30]. HSR has the potential to 
enable more rapid output flows and to optimize the distribution of resources to sustain economic growth [31]. HSR can help to increase productivity and interdependency among companies and cities [32-34]. The HSR effects of space-time compression can accelerate economic growth by reducing the transport and trading costs between cities [35-37]. The employment and knowledge economy will also grow because HSR can help to enhance the flow of information [38].

\subsubsection{Health}

The rapid and systematic urbanization from HSR deployments presented challenges such as the depletion of limited land resources, environmental degradation, air pollution, noise pollution, congested roadways, and poor living conditions, which ultimately affected public health [39-41].

\subsubsection{Resilience}

HSR infrastructure is vulnerable to various threats, including the wearing of parts, terrorist attacks, natural disasters, and spikes in demand [5,42-45]. Even minor disturbances from wind speed variations can affect the normal operation of HSR [46].

\subsubsection{Policy}

Western governments often tie HSR initiatives to policymaking that relate to funding, political leadership, and national goals [47-49]. Applications for federal aid often include independent reviews of potential ridership, modal competition, and other forecasts [50]. Differences in political regimes can influence differences in various aspects of HSR deployments [51].

\subsubsection{Innovations}

Scientific and technical advancements have spurred economic growth [52]. HSR is an important part of contemporary transportation technology innovation to enhance mobility and accessibility [53-57]. Although global economic integration has led to shorter technological innovation cycles, HSR technology developments outside of China were less aggressive.

\subsection{Analysis Technique Classification}

Many analysis methods were applied to assess impacts from HSR deployments. The ten most prevalent methods assessed were difference-in-differences (DID), regression analysis (Regression), simulation-of-scenarios (Simulations), dependencies network analysis (Networks), spatial analysis (Spatial), optimism sentiment analysis (Sentiment), benefitcost-analysis (BCA), game theory (Games), and graph theory (Graph). Table 1 summarizes and describes each method that we listed here. The two most prevalent methods used were DID and Regression. The DID technique is a quantitative and statistical method that was used by most authors $[36,39,56,58-62]$. The second most-used method was Regression, another statistical method used by authors $[24,35,63-67]$ to measure and analyze the relationships between various factors. In Table 1, we have explained each method separately as we mentioned early. 
Table 1. The classification of Methods and their descriptions.

\begin{tabular}{|c|c|c|}
\hline Method & Description of Method & References \\
\hline DID & $\begin{array}{l}\text { Panel data techniques to measure outcome differences } \\
\text { between groups subjected to the variable of interest and } \\
\text { others. This technique is popular in economics to estimate } \\
\text { the effects of sharp changes in the economy and policies. }\end{array}$ & {$[36,39,54-56,58-62,68-71]$} \\
\hline Regression & $\begin{array}{l}\text { The estimation of a function to follow a pattern in data. } \\
\text { The function can make predictions on new data, based on } \\
\text { changes in the variables that "explain" the spread in } \\
\text { the data. }\end{array}$ & {$[23,24,32,35,40,42,44,55,60,63-66,68,72-77]$} \\
\hline Simulations & $\begin{array}{l}\text { The statistical or computer modeling of a process to gain } \\
\text { insights and understanding. An ability to model different } \\
\text { scenarios and outcomes mitigates risks associated with } \\
\text { change management that could otherwise affect the } \\
\text { actual environment. }\end{array}$ & {$[13,46,49,58,78-82]$} \\
\hline Networks & $\begin{array}{l}\text { The depiction of relationships among actors to analyze } \\
\text { social structures and phenomena. Nodes are associated } \\
\text { with actors and their relations as lines among pairs of } \\
\text { nodes that enable the application of matrix algebra and } \\
\text { other mathematical techniques. }\end{array}$ & {$[12,14,41,45,53,81,83-86]$} \\
\hline Spatial & $\begin{array}{l}\text { Analysis of a mapped representation of variables across } \\
\text { space to detect patterns and associations that may suggest } \\
\text { underlying causes of any observed structure. }\end{array}$ & {$[25,29,47,51,55,87-92]$} \\
\hline Sentiment & $\begin{array}{l}\text { Analysis of the extent to which people hold favorable } \\
\text { expectancies for their future. Research linked higher } \\
\text { optimism to higher engagement and lower avoidance. } \\
\text { Optimism is linked to proactive measures for } \\
\text { safeguarding health whereas pessimism is associated with } \\
\text { behaviors that adversely affect health. }\end{array}$ & [93] \\
\hline BCA & $\begin{array}{l}\text { A systematic prediction of social benefits and social costs } \\
\text { to assess the economic effects of suggested public policies } \\
\text { over time. The Benefit-Cost Analysis technique may } \\
\text { incorporate principles of willingness-to-pay and } \\
\text { opportunity cost. The outcome of a BCA is often policy } \\
\text { decisions that would maximize net community benefits in } \\
\text { monetary equivalents. }\end{array}$ & {$[27,83,87,94-97]$} \\
\hline Games & $\begin{array}{c}\text { Study of ways that the interactions among agents and } \\
\text { economic factors produce outcomes relative to } \\
\text { choices made. }\end{array}$ & {$[76,98,99]$} \\
\hline Graphs & $\begin{array}{l}\text { Representation of transport networks as nodes and } \\
\text { weighted links to model and understand flows, } \\
\text { throughput, distributions, mode selection, noise, } \\
\text { bottlenecks, connectivity, accessibility, and other factors. }\end{array}$ & {$[66,68,74,100-102]$} \\
\hline
\end{tabular}

\subsection{Bivariate Frequency Distributions}

Patterns are exposed by using pair-wise combinations of bivariate frequency distributions for seven dimensions of the publications. The selected dimensions are time, frequency, location, publisher, impact area, analytical method, and sentiment. Time was simply the year of the publication. Frequency was a count of the number of publications. Location was the country or region where the article focused the study. The publisher was the journal where the article appeared. The impact area was one of the eight defined and explained previously. The analysis method was one of the ten explained in Table 1 above. Finally, the sentiment was the optimistic or pessimistic outlook of the article, classified as positive, negative, both, and unknown. The sentiment analysis is utilized to assess the effects of impact area as we defined in Section 2.2 on HSR systems. For instance, environmental 
effects on the HSR system were positive [103-105]. It means that implementing HSR could cause the reduction of $\mathrm{CO}_{2}$ in two cities in Turkey. The appendix has all the article mapping tables (AMT) used to create either the univariate or bivariate frequency distributions.

\section{Results}

This section discusses the results of the review based on the combinatorial distributions of articles in time, frequency, location, methods, and sentiment.

\subsection{Journal Distribution}

Figure 1 shows that there has been an exponential increase in the number of relevant articles published since 1997. As we can see in Figure 1, the number of papers published since 1997 has considerably increased from one study to 26 . The reason that the number of articles in 2020 is decreased is due to the limitation that we have considered in this paper. So, the number of papers in 2020 is considered until 1 March 2020.

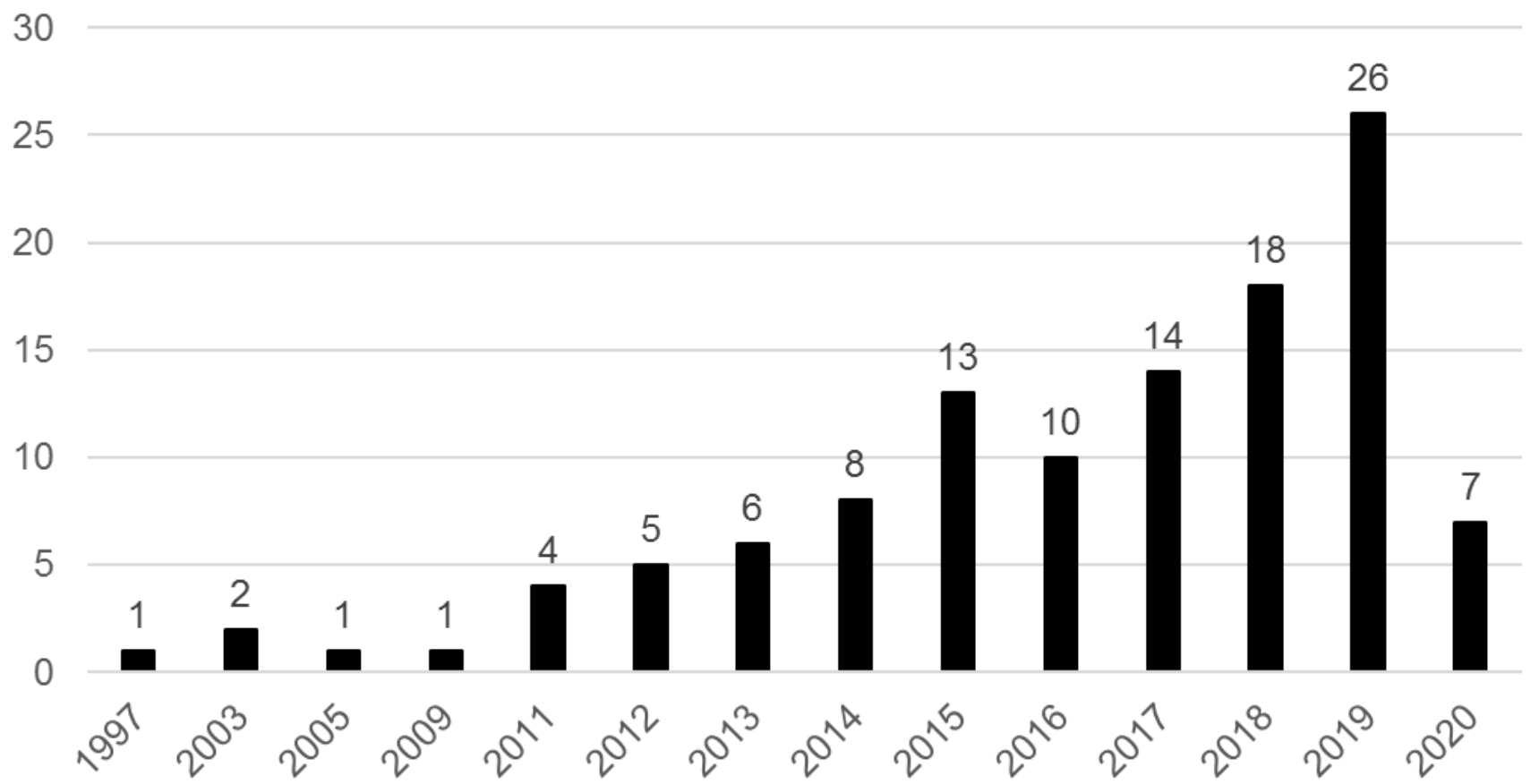

Figure 1. Distribution of articles by year.

Figure 2 categorizes all the articles from 1997 to 2020 by the journal in which they appeared. The journal name is annotated with the current 2-year impact factor (IF). The mean IF, weighted by the frequency of publication, was 1.47. What is clear from Figure 2 is that the highest number of articles published in four journals including Transport Policy, Journal of Transport Geography, Transportation Research Part A, and Transportation Research Part D with 21, 21, 14, and 12 respectively.

Moreover, Table 2 summarizes the scope of the top four journals that contained most of the articles. The policy implications of theoretical analysis and the spatial implications of deployments were dominant themes. 


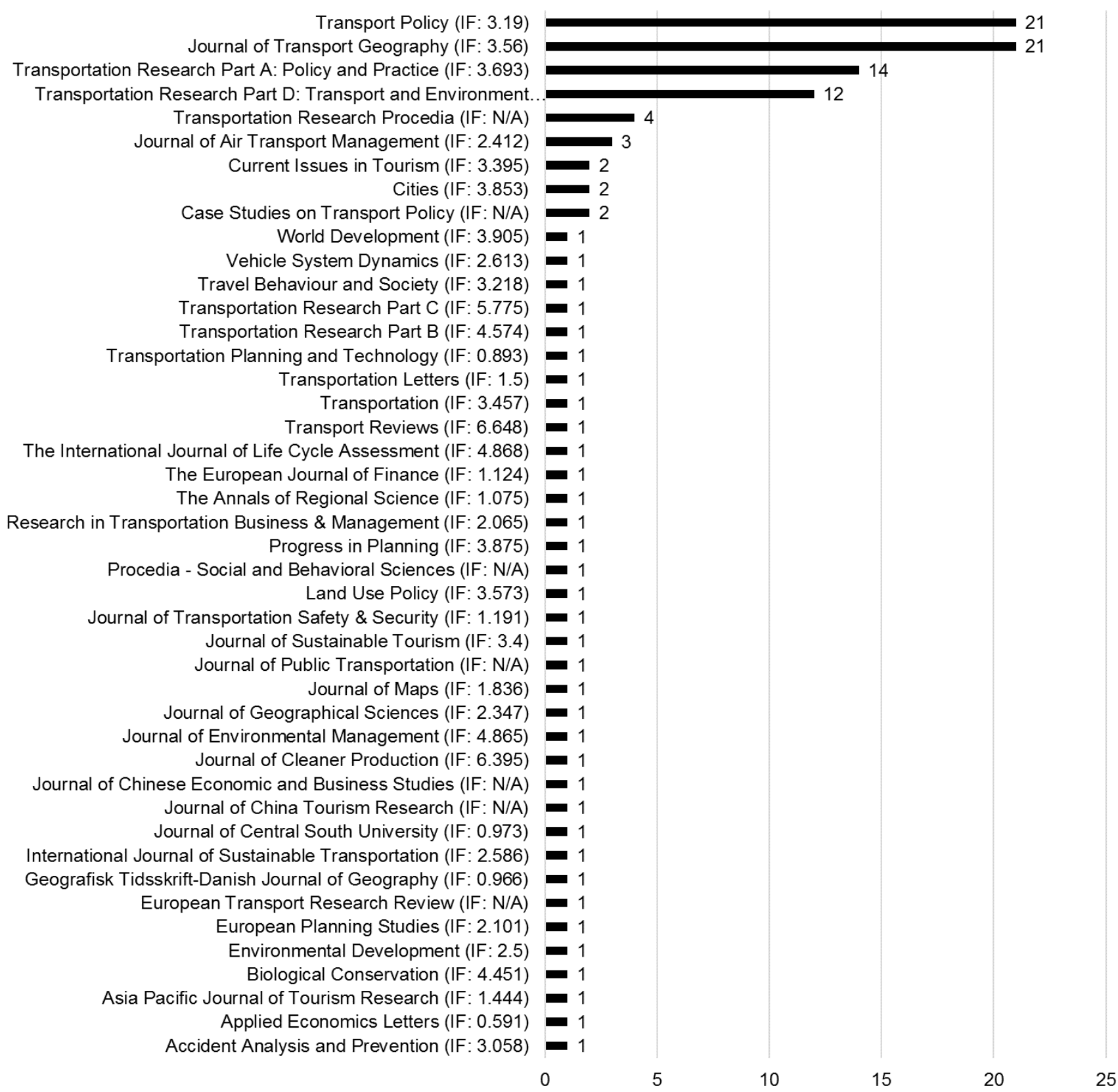

Figure 2. Distribution of the articles used by the journals in which they appeared.

Table 2. Summary of Journal Scope and Articles.

\section{Journal}

Transport Policy

Transport Geography

Summary of Scope

Design of innovative policy, management practices, and applications bridging the gap between transport theory and practice.

\section{Summary of Articles}

Government, management, and industry strategies across all transport modes. Topics include international transport economics, strategies that influence policy, and effects monitoring.

Issues and technological advances spanning the spatial dimensions of transportation, organization, structure, and operations that affect the globalization of economies. Deals with the effects of transport policy and governance on regions and places.
Articles analyze the impacts of transport investment on mobility, livelihoods, social networks, the spatial economy, patterns of development, travel behavior, and accessibility. 
Table 2. Cont.

\begin{tabular}{ccc}
\hline Journal & Summary of Scope & Summary of Articles \\
\hline $\begin{array}{c}\text { Transportation Research Part A: } \\
\text { Policy and Practice }\end{array}$ & $\begin{array}{c}\text { Policy analysis, design, formulation, and } \\
\text { evaluation; planning; interaction with the political } \\
\text { socioeconomic and physical environments; } \\
\text { management and evaluation of transport systems. }\end{array}$ & $\begin{array}{c}\text { The paper focuses on a clear policy } \\
\text { concern with research covering topics } \\
\text { from disciplines including economics, } \\
\text { engineering, psychology, sociology, } \\
\text { and urbanism. }\end{array}$ \\
$\begin{array}{c}\text { Transportation Research Part D: } \\
\text { Transport and Environment }\end{array}$ & $\begin{array}{c}\text { The environmental impacts of transportation and } \\
\text { policy responses, implications for the design, } \\
\text { planning, and management of } \\
\text { transportation systems. }\end{array}$ & $\begin{array}{c}\text { Covers all factors relating to } \\
\text { environmental impacts including, air } \\
\text { quality, ecosystems, global climate, } \\
\text { economic development, quality of life, } \\
\text { public health, and land use. }\end{array}$ \\
\hline
\end{tabular}

\subsection{Location Distribution}

Figure 3 shows the distribution of articles by the region analyzed and the cumulative proportion, ranked by frequency. The cumulative line conveys the dominance of studies within the first few countries and then the gradual increase of studies focused on other countries. The category "Other Countries" includes an analysis of HSR deployments in several countries. China and Spain accounted for $27 \%$ and $13 \%$ of the published articles, respectively. Several authors included multiple countries in their analysis $[12,41,44,47,63,73,76,101]$. In those cases, the articles were mapped to multiple regions.

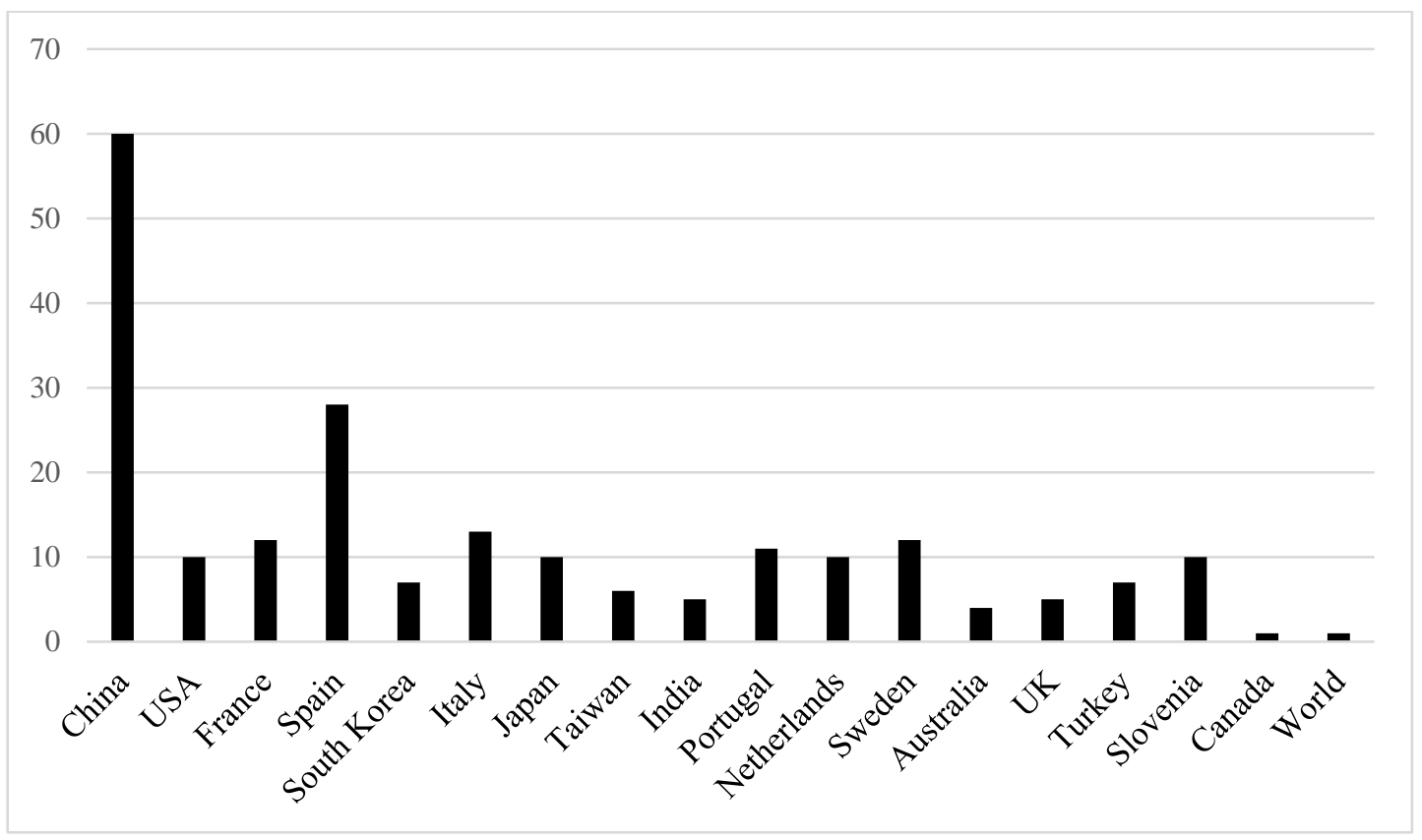

Figure 3. Article volume and region analyzed.

The first high-speed rail system, known as the bullet train, was created in 1964 to link the Japanese cities of Tokyo and Osaka. China has the longest length of HSR in the world with 26,869 km; by comparison, the United Kingdom has about $1377 \mathrm{~km}$ of rail [106]. In 2009, there were more than $12,158 \mathrm{~km}$ of HSR in the world, which increased to more than 78,850 by 2018. Italy [107] the United Kingdom [108] and France [1] were the next countries to make HSR available to the public. In 1981, the French system connected Paris and Lyon with speeds up to $200 \mathrm{~km} / \mathrm{h}$. Today, the French high-speed rail network has expanded to more than $3220 \mathrm{~km}$ of rail networks that allow for speeds of up to $320 \mathrm{~km} / \mathrm{h}$. Germany's development lasted nearly two decades [109] whereas the other developments were complete within 10 years. HSR in China has developed rapidly over the past 15 years 
because of generous funding from their government [110]. In the early 1990s, China started planning the current HSR network as well as the country of Norway [111], modeling it after the Shinkansen system in Japan. Korea began construction shortly after China [112].

Table 3 summarizes the length of a line in operation, under construction, and not started construction [113]. Table 3 is ordered from the largest network to the smallest. Table 3 also includes the year of construction start to the commencement of operations for the first HSR deployment in that country. The last column of Table 3 lists the number of years taken to develop and deploy the first HSR system in each country. The average time is 7.48 years, and the standard deviation is 4.82 years. The average development time for countries in the Asian continent was 8.83 years as compared with 8.25 years for European countries.

Table 3. HSR Deployments. Data Source: International Union of Railways (UIC), 2010 and 2011.

\begin{tabular}{|c|c|c|c|c|c|c|c|}
\hline Country & $\begin{array}{c}\text { Operating } \\
\text { Lines } \\
(\mathbf{k m})\end{array}$ & $\begin{array}{c}\text { New Lines } \\
(\mathrm{km})\end{array}$ & Approved & $\begin{array}{c}\text { Service } \\
\text { Start }\end{array}$ & $\begin{array}{l}\text { Build } \\
\text { Start }\end{array}$ & $\begin{array}{c}\text { Max Speed } \\
(\mathrm{km} / \mathrm{h})\end{array}$ & $\begin{array}{c}\text { Time } \\
\text { (Years) }\end{array}$ \\
\hline China & 26,869 & 10,738 & 1268 & 2008 & 1990 & 380 & 18 \\
\hline Spain & 3100 & 1800 & 471 & 1992 & 1986 & 250 & 6 \\
\hline Japan & 3041 & 402 & 194 & 1964 & 1959 & 320 & 5 \\
\hline France & 3220 & 125 & 0 & 1981 & 1976 & 320 & 5 \\
\hline Germany & 3038 & 330 & 0 & 1991 & 1973 & 300 & 18 \\
\hline Sweden & 1706 & 180 & 0 & 1985 & 1979 & 200 & 6 \\
\hline UK & 1377 & 230 & 320 & 1976 & 1969 & 201 & 7 \\
\hline South Korea & 1104 & 376 & 49 & 2004 & 1992 & 300 & 12 \\
\hline Italy & 999 & 116 & 0 & 1977 & 1970 & 250 & 7 \\
\hline Turkey & 802 & 1208 & 1127 & 2007 & 2003 & 250 & 4 \\
\hline Russia & 845 & 0 & 770 & 2012 & 2009 & 250 & 3 \\
\hline Finland & 609 & 0 & 0 & 2006 & 2005 & 200 & 1 \\
\hline Uzbekistan & 344 & 0 & 0 & 2011 & 2011 & 250 & 0 \\
\hline Austria & 352 & 208 & 0 & 2008 & 1999 & 230 & 9 \\
\hline Taiwan & 354 & 0 & 0 & 2007 & 1998 & 300 & 9 \\
\hline Belgium & 326 & 0 & 0 & 1997 & 1997 & 260 & 5 \\
\hline Poland & 224 & 0 & 484 & 2014 & 2011 & 200 & 3 \\
\hline Netherlands & 175 & 0 & 0 & 2009 & 2000 & 300 & 9 \\
\hline Switzerland & 144 & 15 & 0 & 2005 & 2000 & 200 & 5 \\
\hline Luxembourg & 142 & 0 & 0 & 2007 & 2002 & 320 & 5 \\
\hline Norway & 64 & 54 & 0 & 1998 & 1997 & 210 & 1 \\
\hline USA & 54 & 192 & 1710 & 2030 & 2020 & 240 & 10 \\
\hline Saudi Arabia & 453 & 453 & 0 & 2018 & 2009 & 299 & 9 \\
\hline Denmark & 60 & 56 & 0 & 2019 & 2012 & 180 & 7 \\
\hline Thailand & 0 & 873 & 615 & 2023 & 2017 & 250 & 6 \\
\hline Iran & 0 & 410 & 1351 & 2021 & 2015 & 270 & 6 \\
\hline Indonesia & 0 & 0 & 712 & 2021 & 2015 & 250 & 6 \\
\hline India & 0 & 0 & 508 & 2023 & 2018 & 250 & 5 \\
\hline Malaysia & 0 & 0 & 350 & 2031 & 2019 & 250 & 12 \\
\hline Israel & 0 & 0 & 85 & 2018 & 2001 & 250 & 17 \\
\hline Portugal & 0 & 0 & 550 & 2015 & 2000 & 250 & 15 \\
\hline Czech Rep. & 0 & 0 & 660 & 2030 & 2017 & 250 & 13 \\
\hline Greece & 0 & 500 & 200 & 2021 & 2018 & 250 & 3 \\
\hline
\end{tabular}

Amtrak is a government-owned railroad company that provides high-speed service across only small portions $(55 \mathrm{~km})$ of the system [114-116]. The state of California recently secured funding to solidify plans for a route between Los Angeles and Las Vegas [117].

\subsection{Impact Area Distribution}

Figure 4 shows a frequency distribution in the order of impact area ranking. Figure 5 shows the distribution of articles from 2011 to 2020, subcategorized by impact area. Figure 6 
shows the distribution of articles by impact area, subcategorized by the deployment location analyzed.

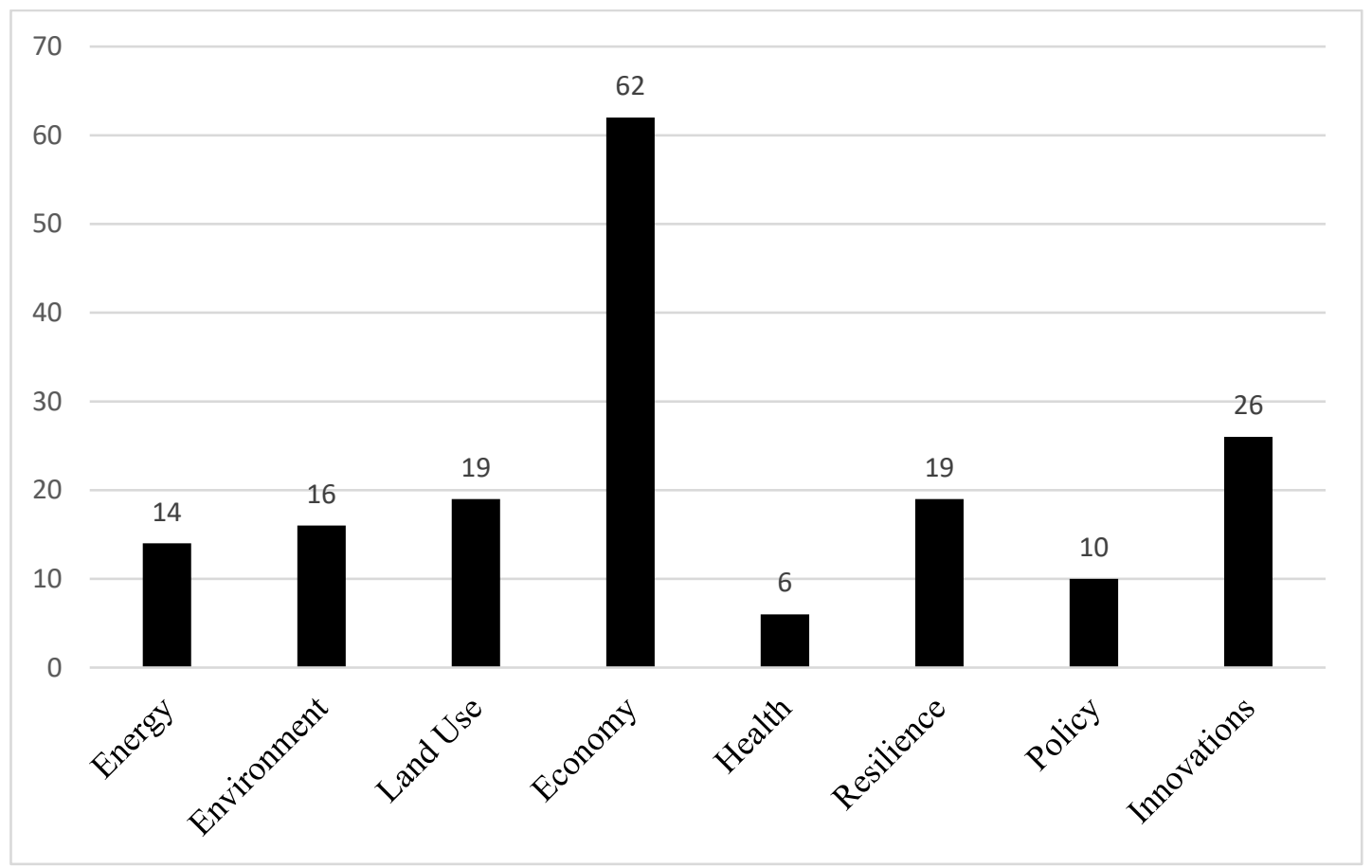

Figure 4. Article volume and impact area.

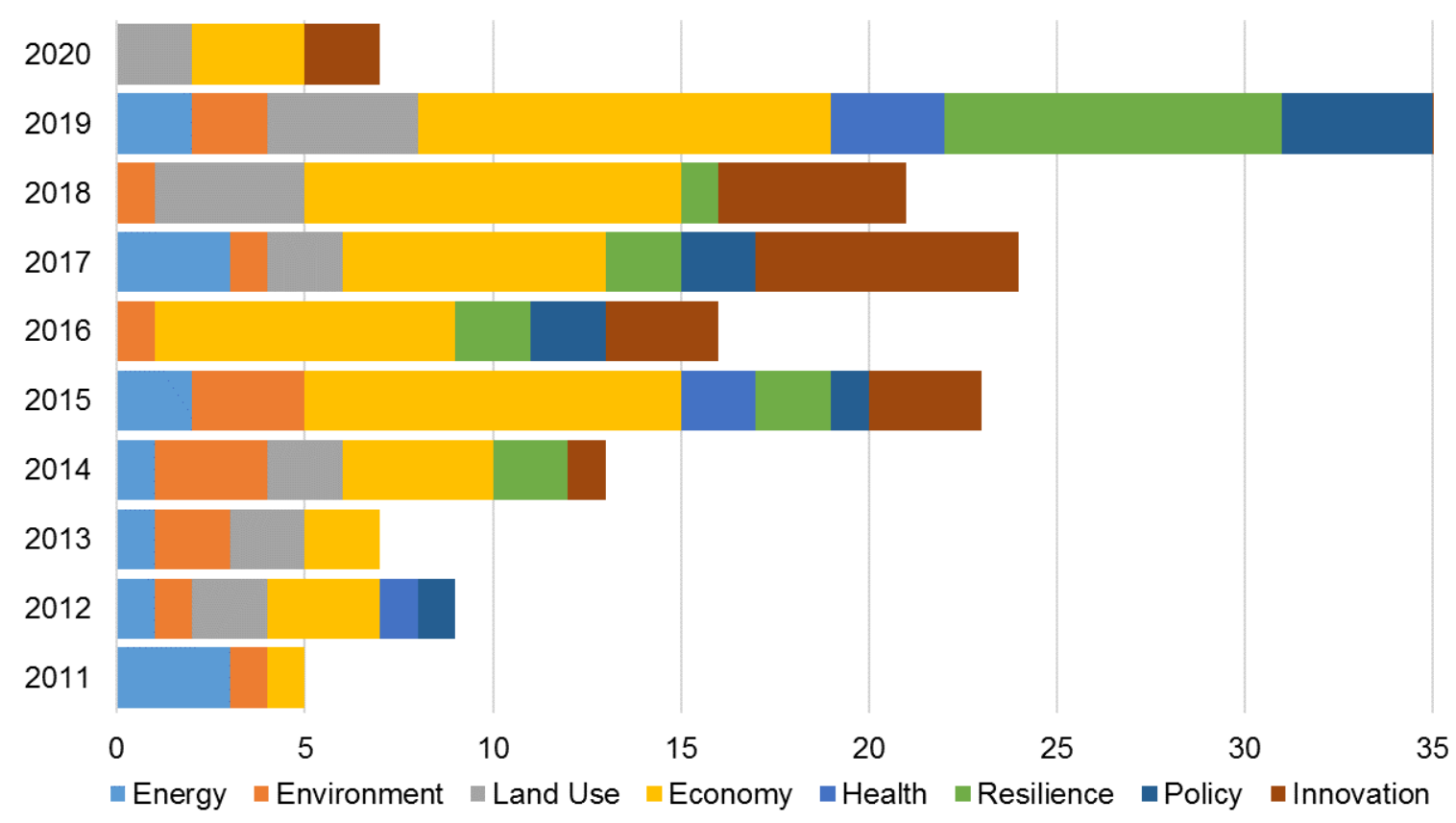

Figure 5. Distribution of articles by year and impact area. 


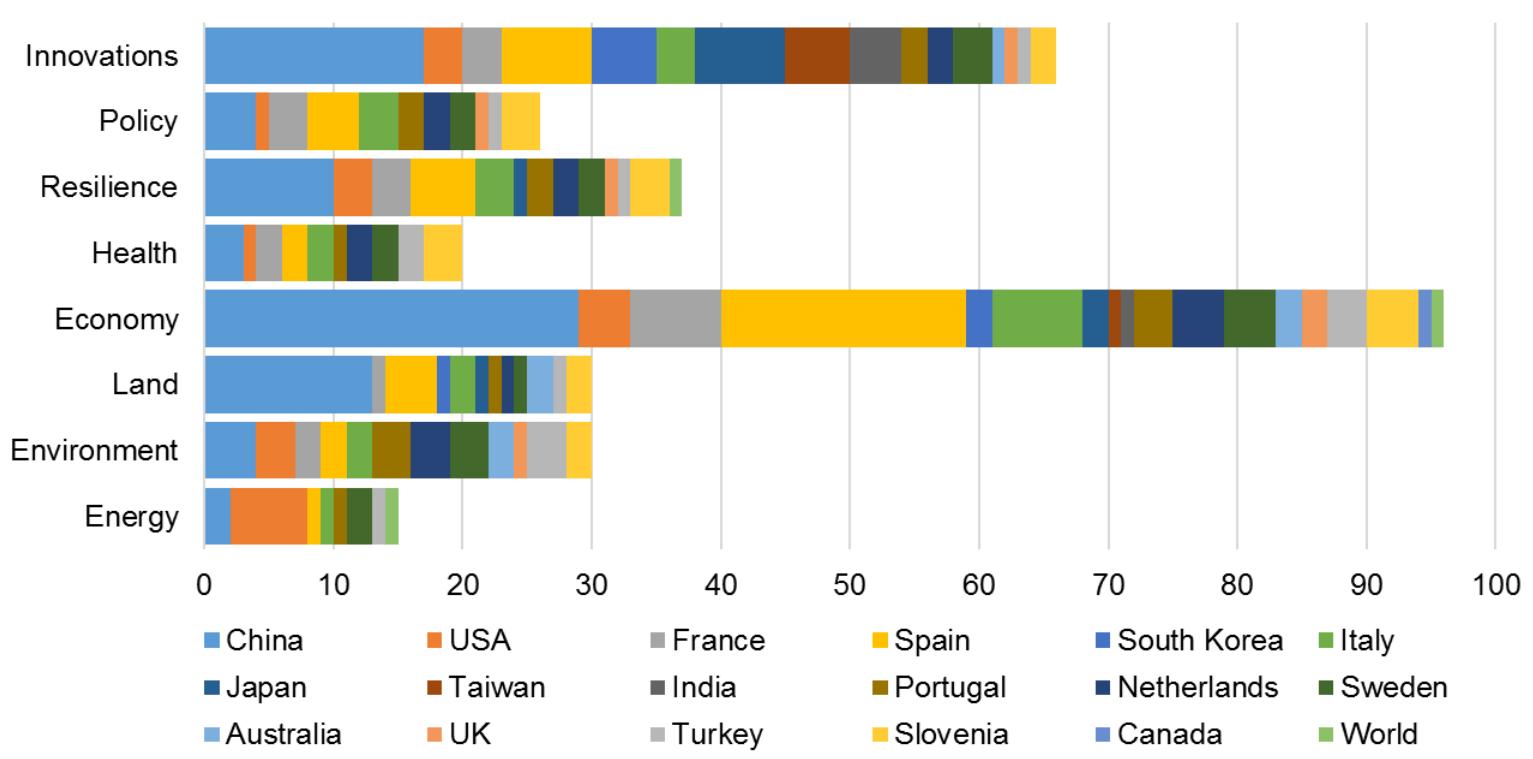

Figure 6. Distribution of articles by impact area and location.

\subsection{Analysis Technique Distribution}

Assessments included a wide range of factors such as deployment cost, travel time, accessibility, life cycle, energy consumption, economic impacts, emissions, fares, speed comfort, demand, impacts on tourism, spatial interactions, changes in land cover, and the opportunity costs of travel time savings. Table A1 in Appendix A summarizes the main assessment from each article. Where articles assessed multiple factors in different regions, using several different techniques, the table lists the dominant factors assessed. The discussion section provides a synthesis of the table with a discussion of the advantages and disadvantages of each method.

Figure 7 shows the distribution of analysis techniques used in HSR analysis. As we can see in Figure 7, the two methods of DID and Regression are among the methods that have been used by many researchers. Figure 8 shows the distribution of the articles by analysis technique, subcategorized by year. Figure 9 shows the distribution of the articles by analysis technique, subcategorized by impact area. Figure 10 shows the distribution of the articles by analysis technique, subcategorized by location.

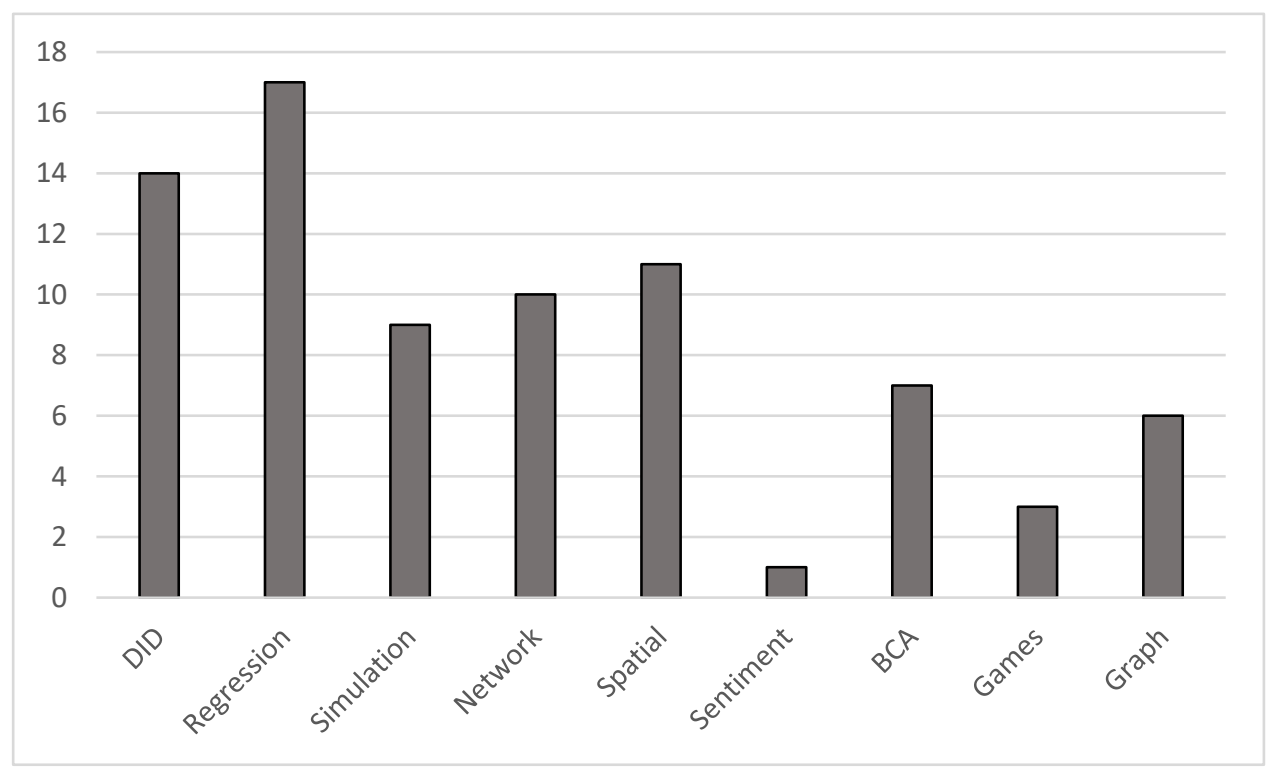

Figure 7. Article volume and proportion by analysis methods. 


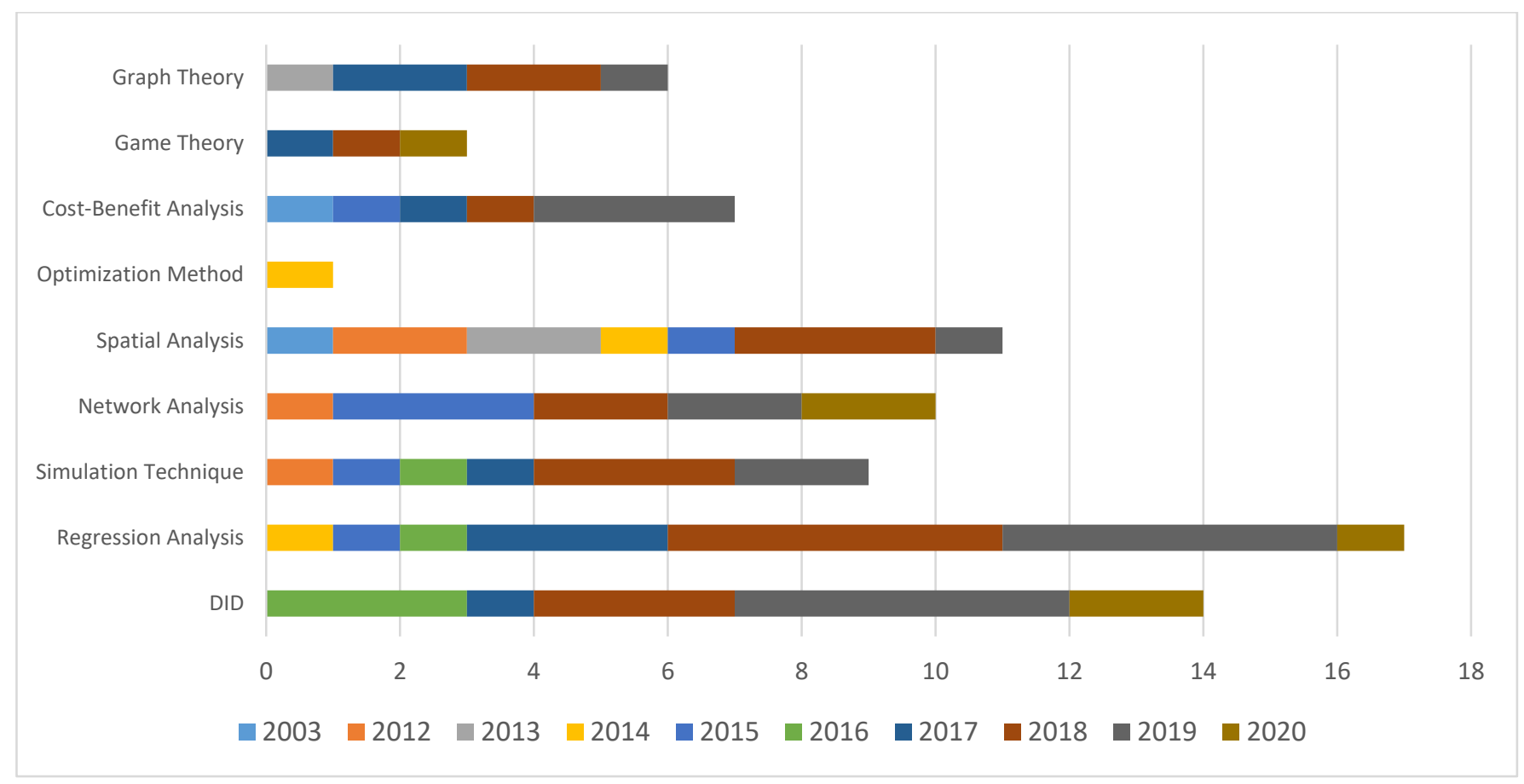

Figure 8. Distribution of articles by year and analysis method.

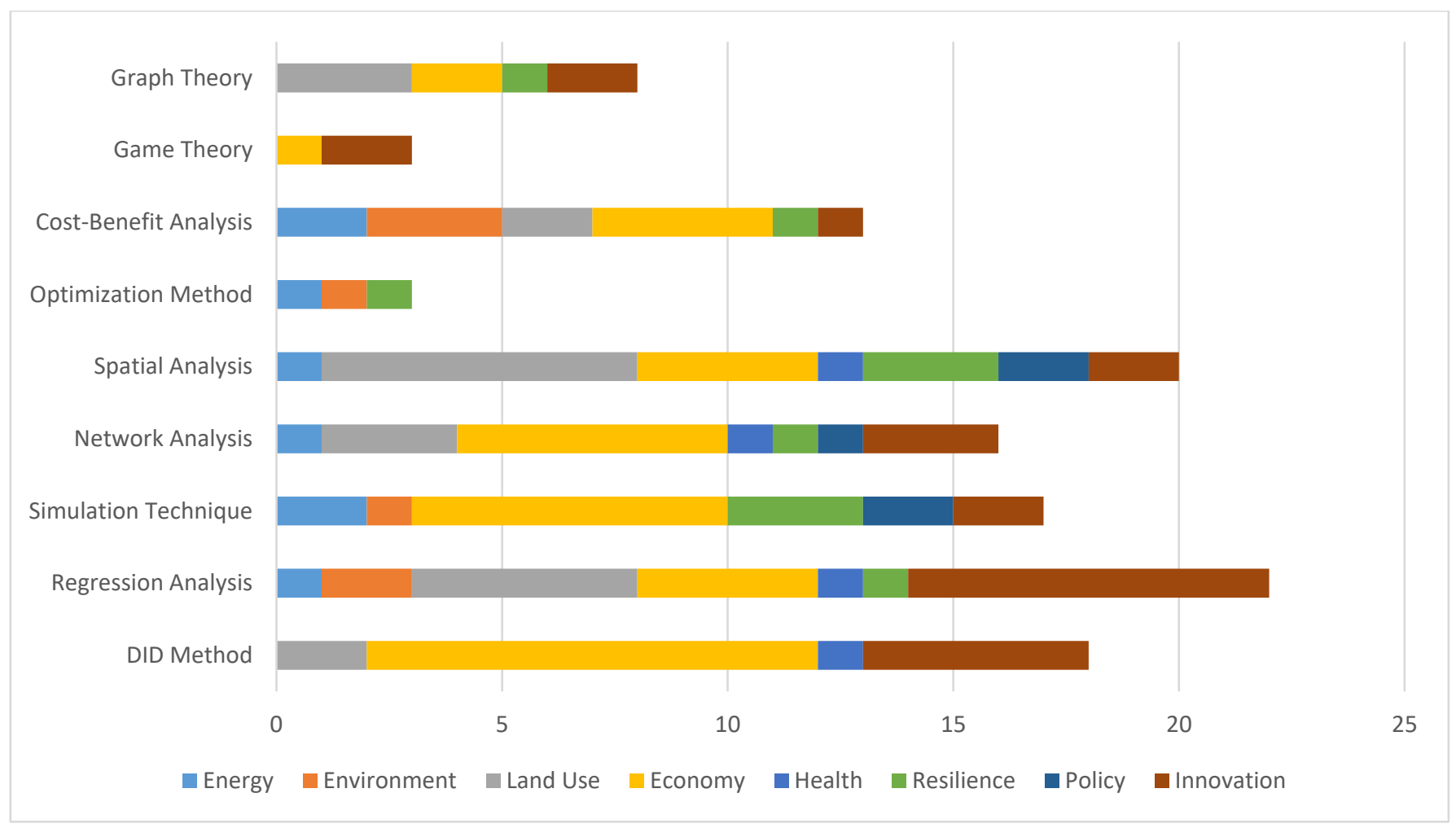

Figure 9. Distribution of articles by analysis method and impact area. 


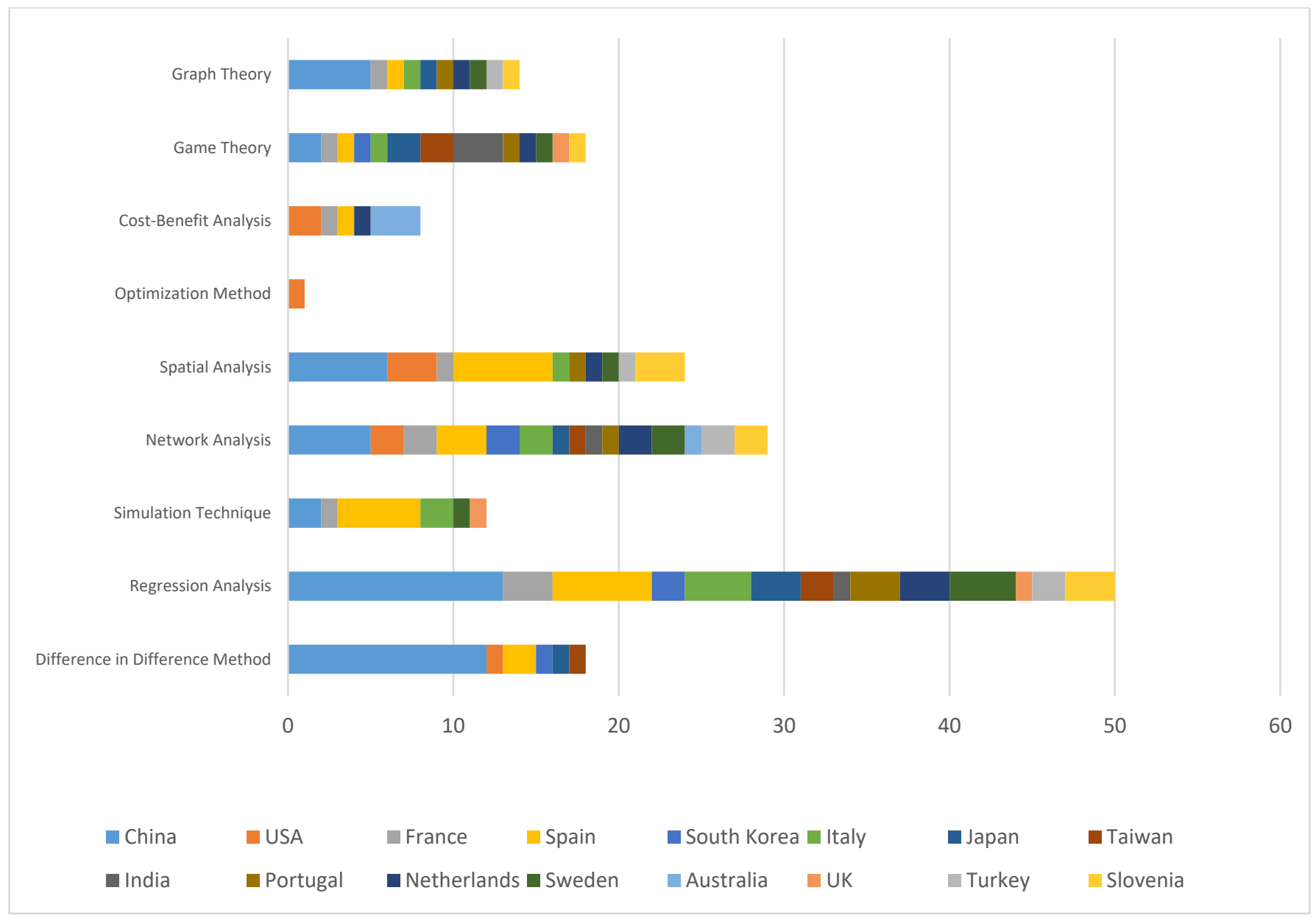

Figure 10. Distribution of articles by analysis method and location.

\subsection{Article Sentiment Distribution}

The result of the assessed article sentiment was based on whether the article suggested or implied that impact or impacts of the investigated factor or factors were positive, negative, both, and unclear. Overall, positive, negative, both, and unknown sentiments accounted for $59.6 \%, 18.4 \%, 12.3 \%$, and $9.6 \%$, respectively.

Figure 11 shows the distribution of publications by year, subcategorized by sentiment. Negative sentiments dominated before 2011, after which positive sentiments began to dominate. Figure 12 shows the distribution of locations, subcategorized by sentiment. Figure 13 shows the distribution of impact areas, subcategorized by sentiment. There were no positive sentiments for articles within the impact area of health. Conversely, there were no negative sentiments for articles addressing policy. Figure 14 shows the distribution of the analysis methods, subcategorized by sentiment. There were no negative sentiments for methods involving graph theory and sentiment analysis. 
2020

2019

2018

2017

2016

2015

2014

2013

2012

2011

2009

2005

2003

1997
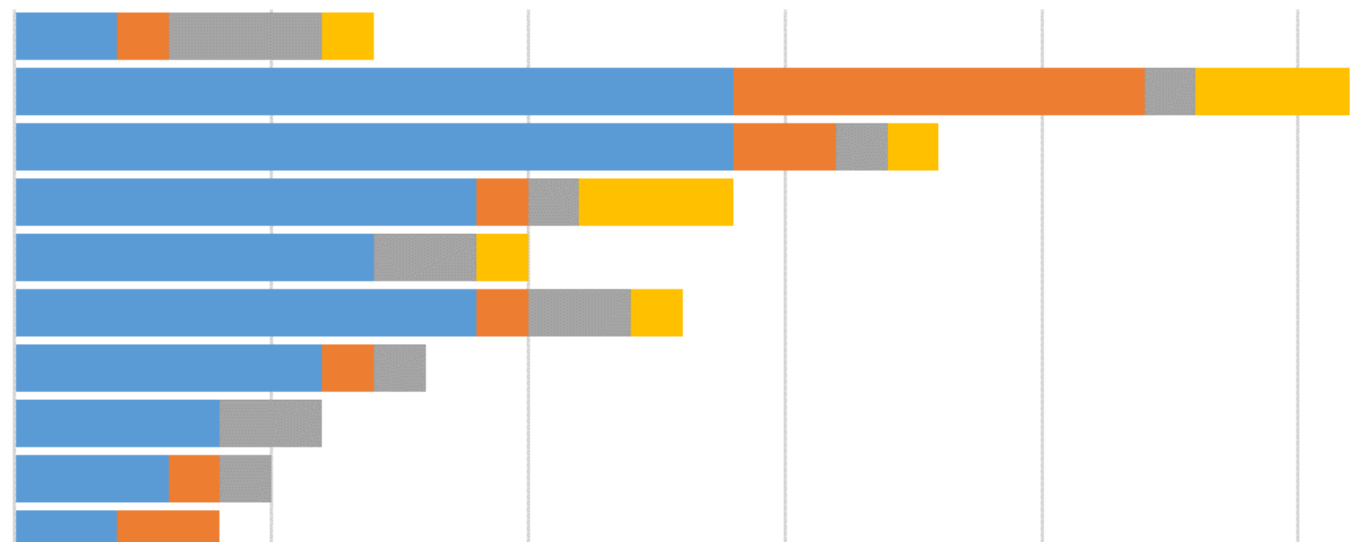

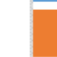

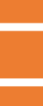

0

5

10

15

20

-Positive $\square$ Negative $\square$ Both $\square$ Unclear

Figure 11. Article distribution by year and sentiment.

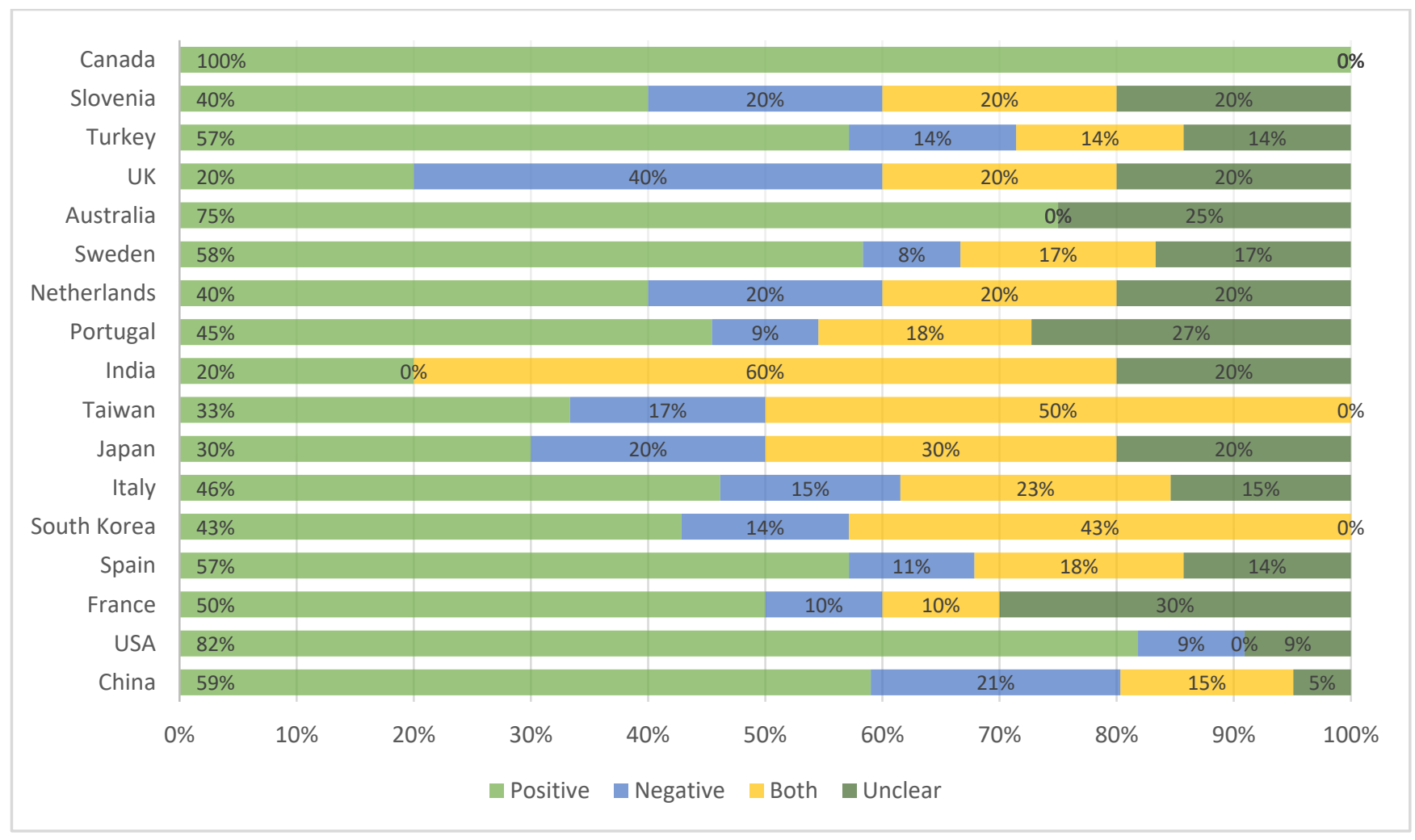

Figure 12. Percentage of articles by location and sentiment. 


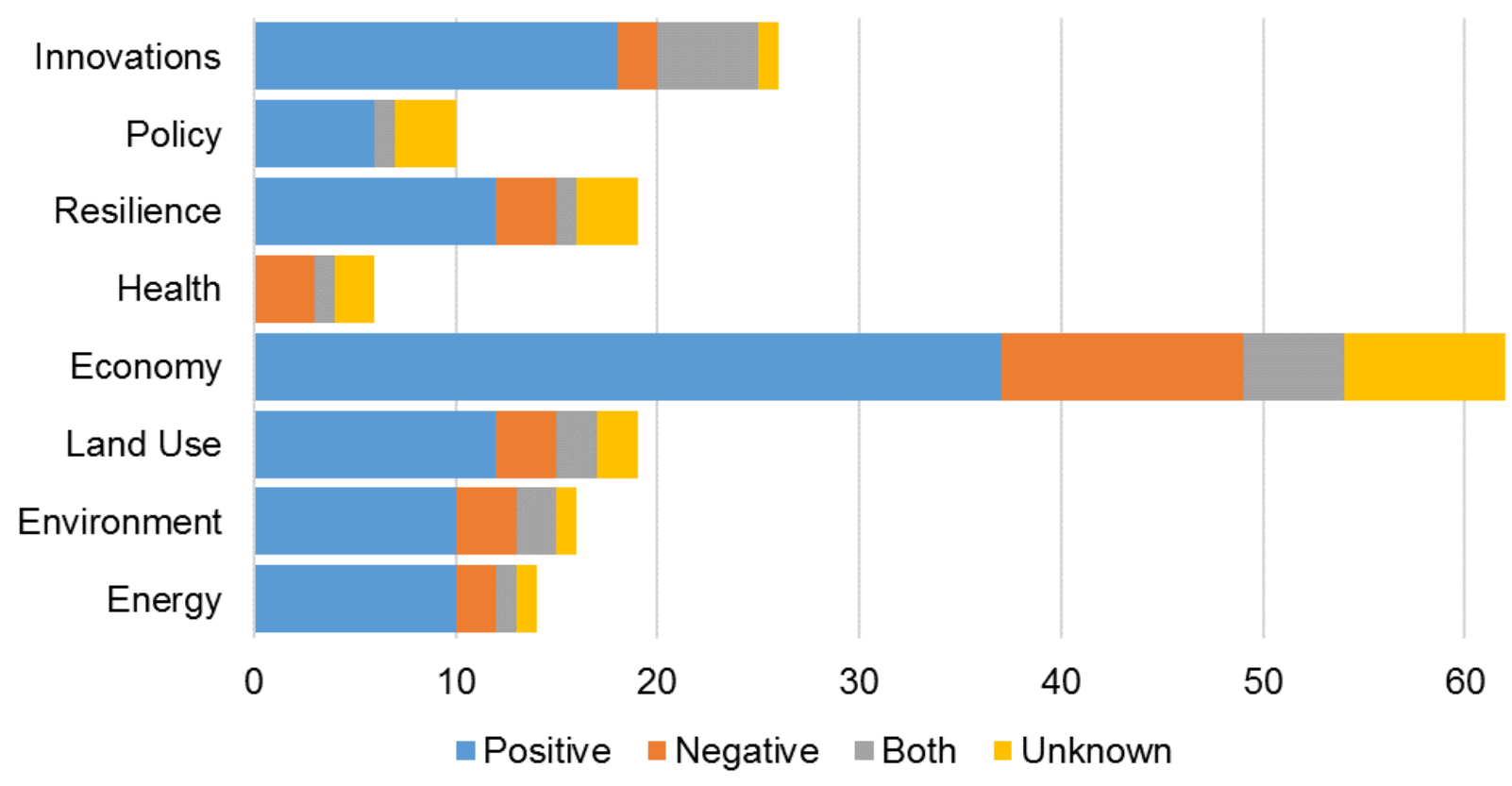

Figure 13. Distribution of articles by impact area and sentiment.

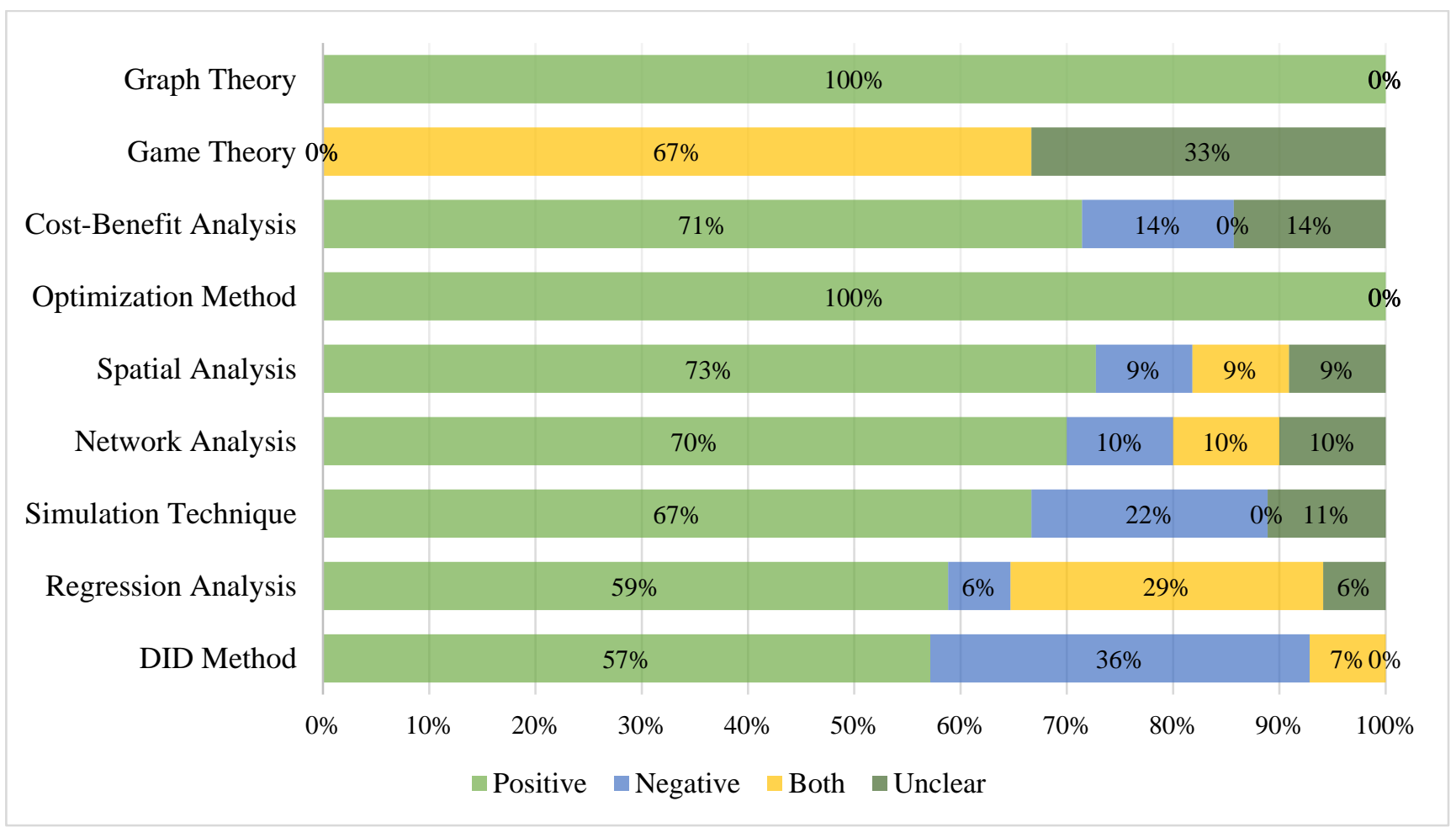

Figure 14. Percentage of articles by analysis method and sentiment.

Figures 15 and 16 are a visualization of the frequency and relationship of keywords from all the articles analyzed. HSR studies involved both reviews and case studies related to impacts and implications on the airline industry and tourism. 


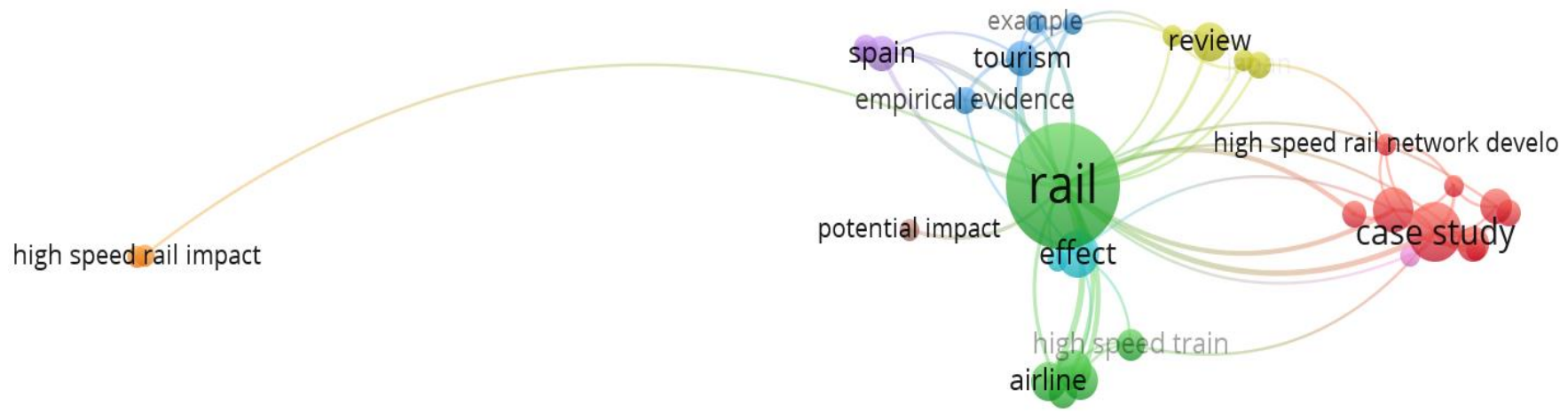

Figure 15. Network of HSR Systems and Case Studies.

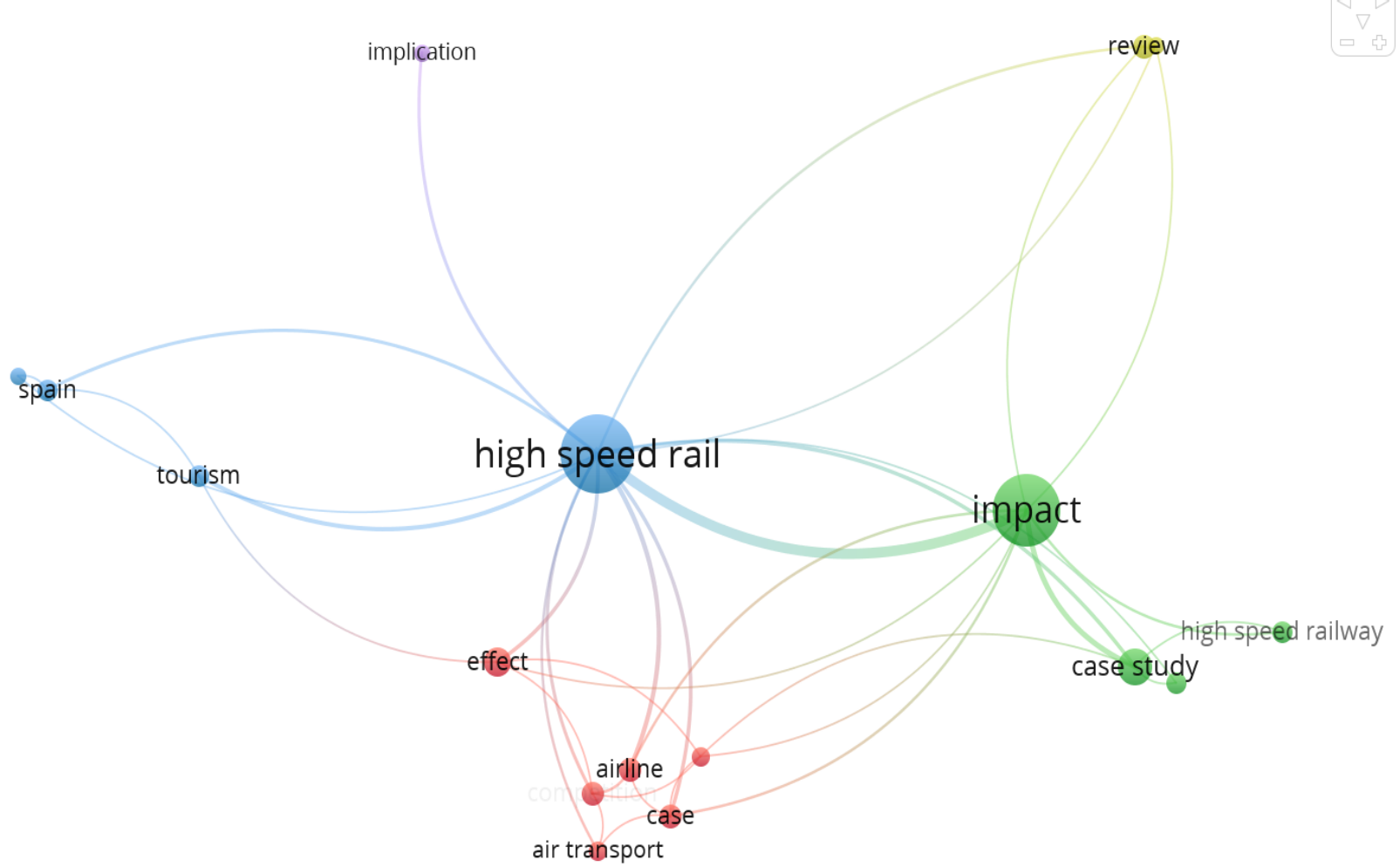

Figure 16. Network of HSR industry and their relationship with other keywords.

\section{Discussion}

This section provides observations about the distributions of the journal articles, the location focus, the impact area assessed, the analysis technique used, and the sentiments conveyed as well as some future research gaps for future research studies.

\subsection{Journal Distribution}

Figure 1 shows that there has been an exponential increase in the number of articles published since 1997, with only five articles from 1997-2010. HSR analysis is published in a wide range of journals, but publications were more highly skewed towards policy and environmental implications. Figure 2 shows that the journals, Transport Policy, Transport Geography, Transportation Research Part A: Policy and Practice, and Transportation Research Part D: Transport and Environment published most of the articles. 


\subsection{Location Distribution}

Figure 17 graphically illustrates the timelines for the first deployments in the selected countries. The pattern indicates that construction can last between 1 and 18 years, and there is no obvious regional correlation to the length of development time. In summary, there was very little difference in the development times between the two regions of the world.

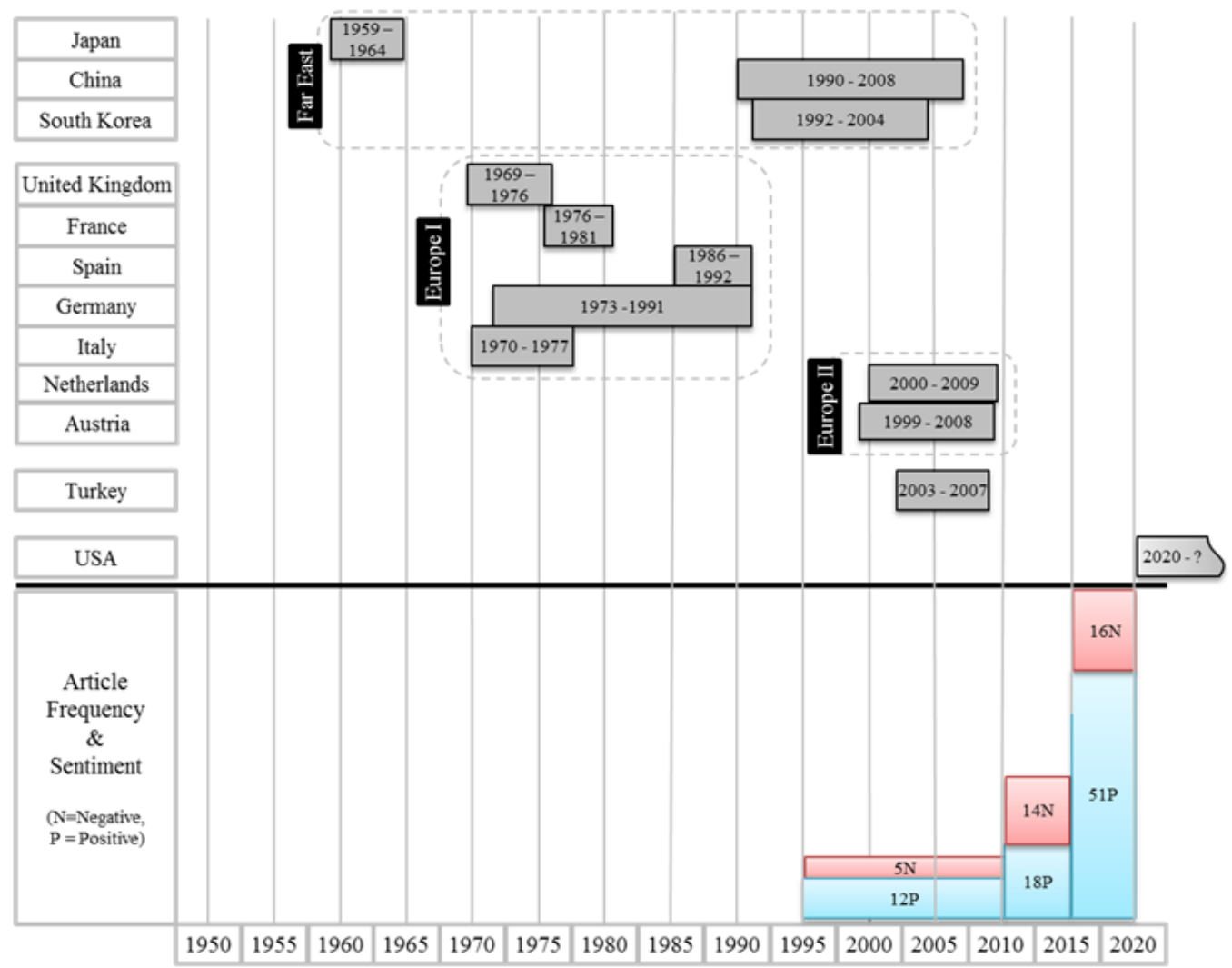

Figure 17. HSR development from funding approval to launch.

The distribution of articles by region analyzed (Figure 3) shows that China, Spain, and Italy accounted for more than half of the articles published. The pattern indicates that there was an acceleration of papers after the second wave of European deployments were complete.

\subsection{Impact Area Distribution}

Figure 4 revealed that HSR impacts of the highest and the lowest interest were economic development and health, respectively. Articles directed at policymaking ranked next to last even though most of the journals in which articles appeared dealt with policy implications. The pattern in Figure 5 shows that studies about HSR impacts on economic development, the environment, and land use were consistent over the years. Topics in innovation emerged after 2014. The pattern in Figure 6 highlights those studies about the impact of HSR on the economic development of China and Spain dominated.

\subsection{Analysis Technique Distribution}

All methods used in this review have advantages and disadvantages as summarized in Table 4. All the methods used were quantitative. The DID and Regression methods were the most popular overall (Figure 7), likely because of their statistical rigor. Although the DID method was most popular overall, it began to appear consistently since 2016 as observed in Figure 8. Similarly, the Regression method began to appear consistently in 2014. The use of game theory emerged after 2017. Simulations were used consistently throughout the years. 
Table 4. Advantages and Disadvantages of Each Method Used.

\begin{tabular}{|c|c|c|}
\hline & Advantage & Disadvantage \\
\hline DID & $\begin{array}{l}\text { A simple method of comparing changes between a } \\
\text { treated and an untreated time series, assuming that the } \\
\text { latter is unaffected but similar. }\end{array}$ & Requires similar and stable data from both series. \\
\hline Regression & $\begin{array}{l}\text { The coefficients of the functional relationship model } \\
\text { can convey the relative importance of variables. }\end{array}$ & $\begin{array}{l}\text { Assumes that the cause-and-effect relationship } \\
\text { between variables remains unchanged. May lead to } \\
\text { erroneous and misleading results if the assumptions } \\
\text { do not hold. }\end{array}$ \\
\hline Simulation & $\begin{array}{l}\text { Provides practical feedback when designing } \\
\text { real-world systems, before construction. Allows for } \\
\text { the efficient exploration of various scenarios before } \\
\text { investments and construction. }\end{array}$ & $\begin{array}{l}\text { Can be computationally intensive, which could delay } \\
\text { results. May not accurately model the phenomenon. }\end{array}$ \\
\hline Network & $\begin{array}{l}\text { Accounts for dependencies and relationships to } \\
\text { produce insights for improving management, } \\
\text { planning, scheduling, and project control. }\end{array}$ & $\begin{array}{l}\text { Evaluations could involve complex interactions that } \\
\text { are difficult to visualize. Could be } \\
\text { computationally complex. }\end{array}$ \\
\hline Spatial & $\begin{array}{l}\text { Accounts for locational aspects of attributes and } \\
\text { considers spatial dependencies and correlations. }\end{array}$ & $\begin{array}{l}\text { Spatial interactions destroy the assumption of } \\
\text { variable independence. }\end{array}$ \\
\hline Sentiment & $\begin{array}{l}\text { Associates' population growth with patterns in } \\
\text { technology adoption based on waves of optimism, } \\
\text { pessimism, and uncertainty in the marketplace. }\end{array}$ & $\begin{array}{l}\text { Does not account for failures in innovation due to fear, } \\
\text { uncertainty, doubt, or reduction of funding and } \\
\text { political support. }\end{array}$ \\
\hline BCA & $\begin{array}{l}\text { Well-studied, simple, objective, and requires goal } \\
\text { settings, for example, payback period. }\end{array}$ & $\begin{array}{l}\text { Benefits often require quantification of intangibles and } \\
\text { require determination of a discount rate, which may } \\
\text { be unknown. }\end{array}$ \\
\hline Graphs & $\begin{array}{l}\text { Well-studied with fertile theoretical constructs that can } \\
\text { represent complex flows and interactions to solve a } \\
\text { wide variety of transport and logistical problems. }\end{array}$ & $\begin{array}{l}\text { Representation of the network may be too simplified } \\
\text { to account for unexpected disruptions such as } \\
\text { terrorism or natural disasters. }\end{array}$ \\
\hline Games & $\begin{array}{c}\text { Often arrives at an optimal strategy when rules are } \\
\text { well-defined. }\end{array}$ & $\begin{array}{l}\text { Complete information is required for all parties } \\
\text { involved. It can involve recursive thinking and } \\
\text { dependencies among opponents, which can be } \\
\text { intractable for humans to follow. }\end{array}$ \\
\hline
\end{tabular}

As observed in the pattern of Figure 9, all methods except Sentiment were applied to the analysis of HSR economic impacts. Except for Sentiment, all other methods were applied in articles that discussed HSR innovation. Only DID, Regression analysis, spatial analysis, and network analysis were used to study the health impacts of HSR. DID and game theory were the only methods not applied to the study of HSR resilience.

Figure 10 revealed some interesting patterns. Curiously, articles that studied HSR deployments in China applied all methods except BCA and sentiment analysis. Similarly, articles about French deployments applied all methods except DID and sentiment analysis. For Spain, the only method not used was sentiment analysis. The Regression method was used to study HSR deployments in all countries except the United States and Australia. Interestingly, the network analysis method was applied to studies of deployments in all countries, except the United Kingdom. Sentiment analysis was applied only to the assessments of U.S. deployments.

\subsection{Article Sentiment Distribution}

Interestingly, the number of articles reporting positive impacts was more than triple the number of those reporting negative impacts. However, most sentiments were negative before 2011 and started to grow in the positive direction thereafter (Figure 11). The sentiments were most balanced for articles published in 2019. Positive comments dominated in most countries. Interestingly, sentiments about deployments in China were more balanced than for any other country (Figure 12). 
There were no positive and no negative sentiments for studies about the health impacts and policy implications of HSR deployments, respectively (Figure 13). Sentiments about economic impacts were more balanced than for the other impact areas studied (Figure 13). Studies using the DID method had a more balanced sentiment than those using the other methods (Figure 14). The sentiment was only positive for studies using sentiment analysis and graph theory.

\subsection{Gap Assessment}

There has been a lack of studies on the short- and long-term effects of HSR deployments on health, including microscopic and macroscopic studies on psychological effects. Figure 4 illustrates that the study of economic impacts dominated with 62 papers whereas only four papers covered health impacts. Furthermore, only one study used sentiment analysis whereas 17 papers used regression as an analytical method. Techniques such as text mining are continuously evolving as an effective method to analyze sentiments on largescale datasets, including social media feeds. Although positive sentiments outweighed negative sentiments, more needs to be understood about underlying reasons for the latter. Another observation is that there were very few assessments about how cultural, social, or political positions, for example on labor laws, right-of-way acquisition, and environmental regulations, correlated with deployment decisions and timelines. Furthermore, there were no tests of a hypothesis that the sudden acceleration in Chinese deployments during the 1990s was associated with enhanced trading with Western nations.

The effective supply of labor is of great significance to economic development. China has the world's largest HSR market and the second-largest air passenger market. Therefore, with regards to the effect of HSR competition on other means of transportation the literature has promising gaps. When the accessibility of a tourist destination is considered, it is unavoidable to face the problem of multiple transport combinations. The opening of HSR directly increases the transportation modes available to tourists. The calculation of the fastest mode of transportation between two places has become the primary task of the measurement of accessibility. These innovations may lead individual rail companies to adopt different solutions depending on their needs and budgets. Additionally, rail lines that anticipate implementing new rail technologies, such as high-speed rail, or that focus on specific types of freight, may implement new technologies optimized for those options. It is unclear how the operational performance of transportation systems may vary among different weather events from an ex-post perspective. The indicator approach may help emergency management agencies recognize the vulnerability of transportation to severe weather events. Although several studies have examined the impact of extreme weather on transportation, the investigation of this issue from the supply-side with a focus on assessing how the on-time performance of transport systems is affected by severe weather has been scant. Future transportation planning agencies need to develop appropriate strategies to further improve system resilience of different modes of transportation to reduce negative consequences caused by future extreme weather events. Future transportation planning needs to facilitate the development of an integrated transportation system to minimize trip disruptions under severe weather events, researchers say. Although some studies have evaluated the effect of High-Speed Rail on the urban tourism economy, gaps in the literature remain. The impact of HSR on tourism has been inadequately analyzed from a comprehensive perspective.

Another thing is that authors should not only pay attention to the development of the central developed cities, but also the development of surrounding underdeveloped cities. The indirect benefit analysis of the new HSR project should include the impact on airfares. Several studies have found significant monopoly premiums on many routes in China's airline market. The introduction of HSR can increase external competition for the airline industry, thus reducing the monopoly and increasing the competition in the high-speed passenger transport market. First, in the short and medium distance of 50-700 km, high-speed rail has overwhelming advantages. Second, the improvement of 
accessibility of small and medium-sized cities is the most significant. The results showed that the impact of HSR on the number of inbound tourists is significantly positive because the attraction of HSR to inbound tourists measures $12 \%$ higher than the attraction of HSR to domestic tourists. Moreover, the impact coefficient on total inbound tourism revenue is $11.2 \%$, but the impact coefficient on domestic tourism revenue is not significant.

\section{Conclusions}

Although extremely expensive to deploy, operate, and maintain, high-speed rail (HSR) positively benefits society. This work revealed that the effects of space-time compression through faster travel provided several economic benefits. Such benefits included lower fuel consumption, job creation, tourism growth, congestion reduction, and enhancements of real estate value along service routes. However, there were also adverse impacts on the environment such as increased pollution, community severance, and risks to biodiversity.

The patterns of article appearance and subject matter covered indicated that interest in the societal effects of HSR sustained an exponential growth since 2011. The exponential growth appeared after the second wave of HSR deployments across Europe. The coverage of HSR deployments in China, Spain, and Italy was dominant. Those countries also had the most extensive HSR infrastructure. The focus of articles on economic, environmental, and land-use impacts remained consistent across time. The articles reviewed revealed mostly positive sentiments about impacts on society. Techniques known for their statistical rigor, such as DID method and Regression analysis, dominated all cross-sections of time, location, impact area, and sentiments assessed.

The authors used all methods except benefit-cost analysis (BCA) and sentiment analysis to analyze deployments in China. Conversely, those methods were used more extensively to analyze deployments in the United States and Europe, suggesting that there were regional differences in influence. These findings suggest that cultural, social, and political differences may influence decisions about HSR deployments in a variety of ways. Therefore, future research will examine how such differences may have influenced HSR deployments in Western, Eastern, and European countries. Factors will include environmental laws, labor laws, land ownership, terrain, and influences by political lobbying from competing modalities such as aviation and trucking.

Author Contributions: Conceptualization, M.M., R.B., Z.D.E. and M.A.; methodology, M.M. and R.B.; validation, M.M., R.B., Z.D.E. and M.A.; formal analysis, M.M., R.B., Z.D.E. and M.A.; investigation, M.M., R.B., Z.D.E. and M.A.; resources, M.M. and R.B.; data curation, M.M. and R.B.; writingoriginal draft preparation, M.M., R.B., Z.D.E. and M.A.; writing-review and editing, M.M., R.B., Z.D.E. and M.A.; visualization, R.B. and Z.D.E.; supervision, R.B.; project administration, M.M. All authors have read and agreed to the published version of the manuscript.

Funding: This research received no external funding.

Institutional Review Board Statement: Not applicable.

Informed Consent Statement: Not applicable.

Data Availability Statement: Not applicable.

Conflicts of Interest: The authors declare no conflict of interest.

\section{Appendix A}

This appendix contains the article mapping tables used to produce the bivariate categorical frequency charts. 
Table A1. Factors Assessed.

\begin{tabular}{|c|c|c|c|c|c|}
\hline Article & Assessment & Article & Assessment & Article & Assessment \\
\hline Campos et al. [5] & $\begin{array}{l}\text { Actual cost values of building and } \\
\text { maintaining a high-speed } \\
\text { rail infrastructure }\end{array}$ & Diao et al. [68] & Rail travel time & Albalate et al. [62] & Tourism outcomes \\
\hline Kerman et al. [20] & Life cycle cost & Wang et al. [61] & $\begin{array}{c}\text { Population mobility and } \\
\text { urbanization }\end{array}$ & Wang et al. [119] & $\begin{array}{l}\text { Volumes, flows, and spatial } \\
\text { patterns of traffic }\end{array}$ \\
\hline Ortega et al. [29] & $\begin{array}{l}\text { The territorial distribution } \\
\text { of accessibility }\end{array}$ & Jin et al. [90] & Regional accessibility & Wang et al. [54] & Travel time and accessibility \\
\hline Sanchez-Mateos et al. [30] & Accessibility of a station & Kaczensky et al. [91] & Brown bears & Dai et al. [82] & $\begin{array}{l}\text { Surrounding subdivided } \\
\text { industries }\end{array}$ \\
\hline Chinowsky et al. [87] & Climate change & Kamga et al. [51] & $\begin{array}{l}\text { Emerging travel trends and the } \\
\text { resurgence of rail transport- } \\
\text { high-speed rail and its station } \\
\text { hubs }\end{array}$ & Yue et al. [19] & Vehicle, infrastructure, operation \\
\hline Jones et al. [120] & $\begin{array}{l}\text { Train manufacturing, train } \\
\text { operation, train maintenance, train } \\
\text { disposal, track construction, track } \\
\text { operation, and maintenance, and } \\
\text { track disposal }\end{array}$ & Alvarez-sanjaime et al. [49] & Vertical structure of the rail sector & Liorca et al. [121] & $\begin{array}{l}\text { The economic, social, and } \\
\text { environmental impacts of } \\
\text { transportation }\end{array}$ \\
\hline Millard-Ball et al. [122] & $\begin{array}{l}\text { Energy use and greenhouse } \\
\text { gas emissions }\end{array}$ & Vikerman et al. [80] & Transport infrastructure & Wang et al. [71] & $\begin{array}{l}\text { Satellite lighting data as the } \\
\text { proxy variable of local economic } \\
\text { development level }\end{array}$ \\
\hline Xu et al. [123] & HSR carriages & Moyano et al. [81] & Accessibility indicators & Zhang et al. [124] & Airline market \\
\hline Chen et al. [84] & $\begin{array}{l}\text { Co-authorship, co-citation, and } \\
\text { keywords co-occurrence in the } \\
\text { preceding part of the text }\end{array}$ & Yu et al. [55] & $\begin{array}{l}\text { Accessibility scores of the future } \\
\text { HSR corridor during peak and } \\
\text { off-peak hours }\end{array}$ & Fengjun et al. [125] & $\begin{array}{c}\text { Transport circle and accessibility } \\
\text { of HSR in East Asia }\end{array}$ \\
\hline Zheng et al. [53] & $\begin{array}{c}\text { The spatial spillover effect of } \\
\text { HSR stations }\end{array}$ & Yin et al. [126] & Tourism spatial interactions & Raturi et al. [99] & $\begin{array}{l}\text { Speed and passengers' } \\
\text { characteristics }\end{array}$ \\
\hline
\end{tabular}


Table A1. Cont.

\begin{tabular}{|c|c|c|c|c|c|}
\hline Article & Assessment & Article & Assessment & Article & Assessment \\
\hline Garmendia et al. [47] & $\begin{array}{l}\text { HSR territorial strategies and } \\
\text { station location }\end{array}$ & Levinson et al. [85] & State of HSR planning & Liu et al. [32] & Tourism arrivals \\
\hline Wang et al. [88] & $\begin{array}{l}\text { Urban tourism and nationwide } \\
\text { accessibility of cities in non-HSR } \\
\text { and HSR networks }\end{array}$ & Zhao et al. [127] & Travel time saving & Sperry et al. [128] & Mode choice \\
\hline Andres et al. [89] & Accessibility indicators & Zhang et al. [129] & Demand & Tsunoda et al. [76] & Profit and social welfare \\
\hline Shaw et al. [130] & $\begin{array}{l}\text { Travel time, travel distance, and } \\
\text { ticket fee. }\end{array}$ & Momenitabar et al. [131] & Travel time saving & Zhang et al. [60] & Air travel demand \\
\hline Shen et al. [25] & Land cover change & Jia et al. [36] & $\begin{array}{l}\text { Transportation development and } \\
\text { economic growth path }\end{array}$ & Chen et al. [77] & $\begin{array}{c}\text { Heterogeneous impacts of HSR } \\
\text { entry on air travel }\end{array}$ \\
\hline Jiao et al. [100] & Passenger trains & Dehdari Ebrahimi et al. [132] & $\begin{array}{l}\text { Geographical coverage and } \\
\text { mode choice }\end{array}$ & Gao et al. [56] & Level of innovation \\
\hline Chen et al. [74] & Regional economic disparity & & & & \\
\hline Xu et al. [97] & $\begin{array}{l}\text { Regional structure index and urban } \\
\text { land development potential index }\end{array}$ & Cascetta et al. [133] & Demand & Li et al. [45] & $\begin{array}{l}\text { Data of running timetable and } \\
\text { position coordinates }\end{array}$ \\
\hline Kim et al. [83] & Station's role & Wang et al. [70] & Journey times & Doomernick et al. [12] & $\begin{array}{l}\text { Network and the rolling } \\
\text { stock assets }\end{array}$ \\
\hline
\end{tabular}




\section{References}

1. Railway-Technology. TGV France High Speed Railways Operated by SNCF-Railway Technology. Available online: https: / / www.railway-technology.com/projects/frenchtgv/ (accessed on 12 June 2020).

2. Lane, B.W. On the utility and challenges of high-speed rail in the United States. J. Transp. Geogr. 2012, 22, 282-284. [CrossRef]

3. Zhenga, S.; Kahn, M.E. China's bullet trains facilitate market integration and mitigate the cost of megacity growth. Econ. Sci. 2013, 110, 1248-1253.

4. Yale. High-Speed Trains Provide Environmental, Social Benefits, Study Says-Yale E360; Yale School of Forestry \& Environmental Studies: New Haven, CT, USA, 2013. Available online: https:/ / e360.yale.edu/digest/high-speed_trains_provide_environmental _social_benefits_study_says (accessed on 12 May 2020).

5. Campos, J.; Rus, G.D. Some stylized facts about high-speed rail: A review of HSR experiences around the world. Transp. Policy 2009, 16, 19-28. [CrossRef]

6. Benefits of High-Speed Rail for the United States-American Public Transportation Association. APTA. Available online: https:// www.apta.com/research-technical-resources/high-speed-passenger-rail/benefits-of-high-speed-rail-for-the-united-states / (accessed on 12 May 2020).

7. Denyer, D.; Tranfield, D. Using qualitative research synthesis to build an actionable knowledge base. Manag. Decis. 2006, 44, 213-227. [CrossRef]

8. Tranfield, D.; Denyer, D.; Smart, P. Towards a Methodology for Developing Evidence-Informed Management Knowledge by Means of Systematic Review. Br. J. Manag. 2003, 14, 207-222. [CrossRef]

9. Harden, A.; Thomas, J. Methodological Issues in Combining Diverse Study Types in Systematic Reviews. Int. J. Soc. Res. Methodol. 2005, 3, 8. [CrossRef]

10. Boyack, K.W.; Klavans, R.; Börner, K. Mapping the backbone of science. Scientometrics 2005, 64, 351-374. [CrossRef]

11. Leeuwen, T.V. The application of bibliometric analyses in the evaluation of social science research. Who benefits from it, and why it is still feasible. Scientometrics 2006, 66, 133-154. [CrossRef]

12. Doomernik, J.E. Performance and Efficiency of High-speed Rail Systems. Transp. Res. Procedia 2015, 8, 136-144. [CrossRef]

13. Chiara, B.D.; Franco, D.D.; Coviello, N.; Pastrone, D. Comparative specific energy consumption between air transport and high-speed rail transport: A practical assessment. Transp. Res. Part D Transp. Environ. 2017, 52, 227-243.

14. Krishnan, V.; Kastrouni, E.; Pyrialakou, V.D.; Gkritza, K.; McCalley, J.D. An optimization model of energy and transportation systems: Assessing the high-speed rail impacts in the United States. Transp. Res. Part C 2015, 54, 131-156. [CrossRef]

15. Rozycki, C.V.; Koeser, H.; Schwarz, H. Ecology profile of the german high-speed rail passenger transport system, ICE. Int. J. Life Cycle Assess. 2003, 8, 83-91. [CrossRef]

16. Zhang, S.; Zhang, W.; Li, Y.; Gao, L.; Gao, L.; Shaohui, Y. The Production of Carbon Nano-Onions and Wheat Stalk Nano-Chains over Stainless Steel Supported $\mathrm{La}_{0.95} \mathrm{Mg}_{0.05} \mathrm{Ni}_{0.8} \mathrm{Co}_{0.2} \mathrm{O}_{3}$ Catalyst. Synth. React. Inorg. Metal-Org. Nano-Metal Chem. 2013, 44, 222-226. [CrossRef]

17. Miyoshi, C.; Givoni, M. The Environmental Case for the High-Speed Train in the UK: Examining the London-Manchester Route. Int. J. Sustain. Transp. 2014, 8, 107-126. [CrossRef]

18. Chester, M.; Horvath, A. High-speed rail with emerging automobiles and aircraft can reduce environmental impacts in Californias future. Environ. Res. Lett. 2012, 7, 11. [CrossRef]

19. Yue, Y.; Wang, T.; Liang, S.; Yang, J.; Houa, P.; Qu, S.; Zhou, J.; Jiae, X.; Wang, H.; Xu, M. Life cycle assessment of High-Speed Rail in China. Transp. Res. Part D Transp. Environ. 2015, 41, 367-376. [CrossRef]

20. Kerman, J. The role of high-speed rail in mitigating climate change-The Swedish case Europabanan from a life cycle perspective. Transp. Res. Part D Transp. Environ. 2011, 16, 208-217.

21. Bueno, G.; Hoyosb, D.; Capellán-Pérez, I. Evaluating the environmental performance of the high-speed rail project in the Basque Country, Spain. Res. Transp. Econ. 2017, 62, 44-56. [CrossRef]

22. Robertson, $\mathrm{S}$. The potential mitigation of $\mathrm{CO}_{2}$ emissions via modal substitution of high-speed rail for short-haul air travel from a life cycle perspective-An Australian case study. Transp. Res. Part D Transp. Environ. 2016, 46, 365-380. [CrossRef]

23. Sun, Y.-Y.; Lin, Z.-W. Move fast, travel slow: The influence of high-speed rail on tourism in Taiwan. J. Sustain. Tour. 2018, 26, 433-450.

24. Guirao, B.; Lara-Galera, A.; LuisCampa, J. High-Speed Rail commuting impacts on labor migration: The case of the concentration of metropolis in the Madrid functional area. Land Use Policy 2017, 66, 131-140. [CrossRef]

25. Shen, Y.; Silva, J.d.A.e.; Martínez, L.M. Assessing High-Speed Rail's impacts on land cover change in large urban areas based on spatial mixed logit methods: A case study of Madrid Atocha railway station from 1990 to 2006. J. Transp. Geogr. 2014, 41, 184-196.

26. Gospodini, A. Urban development, redevelopment and regeneration encouraged by transport infrastructure projects: The case study of 12 European cities. Eur. Plan. Stud. 2007, 13, 1083-1111. [CrossRef]

27. Chèze, C.; Nègre, R. Wider economic impacts of high-speed rail: Example of agglomeration benefits assessment on Bretagne Pays de Loire high-speed rail project. Transp. Res. Procedia 2017, 25, 5307-5324. [CrossRef]

28. Brenner, N. Globalisation as reterritorialization: The re-scaling of urban governance in the European Union. Urban Stud. 1999, 36, 431-451. [CrossRef] 
29. Ortega, E.; López, E.; Monzón, A. Territorial cohesion impacts of high-speed rail at different planning levels. J. Transp. Geogr. 2012, 24, 130-141. [CrossRef]

30. Sánchez-Mateos, H.S.M.; Givoni, M. The accessibility impact of a new High-Speed Rail line in the UK-A preliminary analysis of winners and losers. J. Transp. Geogr. 2012, 25, 105-114. [CrossRef]

31. Sousa, C.; Roseta-Palma, C.; Martins, L.F. Economic growth and transport: On the road to sustainability. Nat. Resour. Forum 2015, 39, 3-14. [CrossRef]

32. Liu, Y.; Shi, J. How inter-city high-speed rail influences tourism arrivals: Evidence from social media check-in data. Curr. Issues Tour. 2019, 22, 1025-1042. [CrossRef]

33. Hiramatsu, T. Unequal regional impacts of high-speed rail on the tourism industry: A simulation analysis of the effects of KyushuShinkansen. Transportation 2018, 45, 677-701. [CrossRef]

34. Diego, P. Agglomeration and cross-border infrastructure. EIB Pap. 2008, 13, 102-124.

35. Li, X.; Huang, B.; Li, R.; Zhang, Y. Exploring the impact of high-speed railways on the spatial redistribution of economic activities-Yangtze River Delta urban agglomeration as a case study. J. Transp. Geogr. 2016, 57, 194-206.

36. Jia, S.; Zhou, C.; Qin, C. No difference in effect of high-speed rail on regional economic growth based on match effect perspective? Transp. Res. Part A Policy Pract. 2017, 106, 144-157. [CrossRef]

37. Aletà, N.B.; Alonso, C.M.; Ruiz, R.M.A. Smart Mobility and Smart Environment in the Spanish cities. Transp. Res. Procedia 2017, 24, 163-170. [CrossRef]

38. Chen, C.-L.; Hall, P. The wider spatial-economic impacts of high-speed trains: A comparative case study of Manchester and Lille sub-regions. J. Transp. Geogr. 2012, 24, 89-110. [CrossRef]

39. Yuan, H.; Wang, K.; Yang, H.; Wang, C. The impact of rail dispatch system reform on import by rail-Empirical evidence from a natural experiment in China. Transp. Policy 2019, 79, 165-176. [CrossRef]

40. Ye, L.; Liu, S.; Chu, F.; Zhang, Q.; Guo, M. Effects of personality on job burnout and safety performance of high-speed rail drivers in China: The mediator of organizational identification. J. Transp. Saf. Secur. 2019, 13, 695-713. [CrossRef]

41. D'Alfonso, T.; Jiang, C.; Bracaglia, V. Would competition between air transport and high-speed rail benefit environment and social welfare? Transp. Res. Part B 2015, 74, 118-137. [CrossRef]

42. Bugalia, N.; Maemura, Y.; Ozawa, K. Demand risk management of private High-Speed Rail operators: A review of experiences in Japan and Taiwan. Transp. Policy 2019, in press. [CrossRef]

43. He, G.; Mol, A.P.J.; Lu, Y. Public protests against the Beijing-Shenyang high-speed railway in China. Transp. Res. Part D Transp. Environ. 2016, 43, 1-16. [CrossRef]

44. Woodburn, A. Rail network resilience and operational responsiveness during unplanned disruption: A rail freight case study. J. Transp. Geogr. 2019, 77, 59-69. [CrossRef]

45. Li, T.; Rong, L.; Yan, K. Vulnerability analysis and critical area identification of public transport system: A case of high-speed rail and air transport coupling system in China. Transp. Res. Part A 2019, 127, 55-70.

46. Liu, D.; Wang, Q.; Zhong, M.; Lu, Z.; Wang, J.; Wang, T.; Lv, S. Effect of wind speed variation on the dynamics of a high-speed train. Int. J. Veh. Mech. Mobil. 2019, 57, 247-268. [CrossRef]

47. Garmendia, M.; Ribalaygua, C.; Urena, J.M. High-speed rail: Implication for cities. Cities 2012, 29, s26-s31. [CrossRef]

48. Zembri, P.; Libourel, E. Towards oversized high-speed rail systems? Some lessons from France and Spain. Transp. Res. Procedia 2017, 25, 368-385.

49. Álvarez-SanJaime, Ó.; Cantos-Sanchez, P.; Moner-Colonques, R.; Sempere-Monerris, J.J. Rail access charges and internal competition in high speed trains. Transp. Policy 2016, 49, 184-195. [CrossRef]

50. Zhang, R.; Johnson, D.; Zhao, W.; Nash, C. Competition of airline and high-speed rail in terms of price and frequency: Empirical study from China. Transp. Policy 2019, 78, 8-18. [CrossRef]

51. Kamga, C. Emerging travel trends, high-speed rail, and the public reinvention of U.S. transportation. Transp. Policy 2015, 37, 111-120. [CrossRef]

52. Guo, B.; Ke, J. The Impacts of High-speed Rail on Sustainable Economic Development: Evidence from the Central Part of China. Sustainability 2020, 12, 2410. [CrossRef]

53. Zheng, L.; Long, F.; Chang, Z.; Ye, J. Ghost town or city of hope? The spatial spillover effects of high-speed railway stations in China. Transp. Policy 2019, 81, 230-241. [CrossRef]

54. Wang, L.; Liu, Y.; Sun, C.; Liu, Y. Accessibility impact of the present and future high-speed rail network: A case study of Jiangsu Province, China. J. Transp. Geogr. 2016, 54, 161-172. [CrossRef]

55. Yu, M.; Fan, W. Accessibility impact of future high-speed rail corridor on the piedmont Atlantic megaregion. J. Transp. Geogr. 2018, 73, 1-12. [CrossRef]

56. Gao, Y.; Zheng, J. The impact of high-speed rail on innovation: An empirical test of the companion innovation hypothesis of transportation improvement with China's manufacturing firms. World Dev. 2020, 127, 104838.

57. Arani, M.; Rezvani, M.M.; Davarikia, H.; Chan, Y. Routing of Electric Vehicles in a Stochastic Network with Non-recurrent Incidents: Behavioral Interpretation of Dynamic Traffic Assignment. ASCE-ASME J. Risk Uncertain. Eng. Syst. Part A Civil Eng. 2020, 6, 25-35.

58. Li, H.; Strauss, J.; Lu, L. The impact of high-speed rail on civil aviation in China. Transp. Policy 2019, 74, 187-200. [CrossRef] 
59. Zhang, F.; Wang, F.; Ou, J.; Yao, S. Role of high-speed rail on social fixed assets investments in China. J. Chin. Econ. Bus. Stud. 2019, 17, 221-244. [CrossRef]

60. Zhang, F.; Graham, D.J.; Wong, M.S.C. Quantifying the substitutability and complementarity between high-speed rail and air transport. Transp. Res. Part A Policy Pract. 2018, 118, 191-215. [CrossRef]

61. Wang, F.; Wei, X.; Liu, J.; He, L.; Gao, M. Impact of high-speed rail on population mobility and urbanization: A case study on Yangtze River Delta urban agglomeration, China. Transp. Res. Part A Policy Pract. 2019, 127, 99-114.

62. Albalate, D.; Fageda, X. High-speed rail and tourism: Empirical evidence from Spain. Transp. Res. Part A Policy Pract. 2016, 85, 174-185.

63. Clewlow, R.R.; Sussman, J.M.; Balakrishnan, H. The impact of high-speed rail and low-cost carriers on European air passenger traffic. Transp. Policy 2014, 33, 136-143. [CrossRef]

64. Wang, L. High-speed rail services development and regional accessibility restructuring in megaregions: A case of the Yangtze River Delta, China. Transp. Policy 2018, 72, 34-44. [CrossRef]

65. Pagliara, F.; Mauriello, F. Modelling the impact of High-Speed Rail on tourists with Geographically Weighted Poisson Regression. Transp. Res. Part A Policy Pract. 2020, 132, 780-790. [CrossRef]

66. Liu, S.; Wan, Y.; Ha, H.K.; Yoshida, Y.; Zhang, A. Impact of high-speed rail network development on airport traffic and traffic distribution: Evidence from China and Japan. Transp. Res. Part A Policy Pract. 2019, 127, 115-135. [CrossRef]

67. Chen, Z. Measuring the regional economic impacts of highspeed rail using a dynamic SCGE model: The case of China. Eur. Plan. Stud. 2019, 27, 483-512.

68. Diao, M. Does growth follow the rail? The potential impact of high-speed rail on the economic geography of China. Transp. Res. Part A 2018, 113, 279-290. [CrossRef]

69. Yang, Z.; Li, T. Does high-speed rail boost urban tourism economy in China? Curr. Issues Tour. 2019, 23, 1973-1989. [CrossRef]

70. Wang, L.; Liu, Y.; Liu, Y.; Sun, C.; Huang, Q. Use of isochrone maps to assess the impact of high-speed rail network development on journey times: A case study of Nanjing city, Jiangsu province, China. J. Maps 2016, 12, 514-519. [CrossRef]

71. Wang, C.; Meng, W.; Hou, X. The impact of high-speed rails on urban economy: An investigation using night lighting data of Chinese cities. Res. Transp. Econ. 2020, 80, 100819. [CrossRef]

72. Chen, Z.; Wang, Y. Impacts of severe weather events on high-speed rail and aviation delays. Transp. Res. Part D Transp. Environ. 2019, 69, 168-183.

73. Zhang, A.; Wan, Y.; Yang, H. Impacts of high-speed rail on airlines, airports and regional economies: A survey of recent research. Transp. Policy 2019, 81, A1-A19. [CrossRef]

74. Chen, Z.; Haynes, K.E. Impact of high-speed rail on regional economic disparity in China. J. Transp. Geogr. 2017, 65, 80-91.

75. Chen, Z.; Haynes, K.E. Impact of high-speed rail on housing values: An observation from the Beijing-Shanghai line. J. Transp. Geogr. 2015, 43, 91-100. [CrossRef]

76. Tsunoda, Y. Transportation policy for high-speed rail competing with airlines. Transp. Res. Part A 2018, 116, 350-360.

77. Chen, Z.; Wang, Z.; Jiang, H. Analyzing the heterogeneous impacts of high-speed rail entry on air travel in China: A hierarchical panel regression approach. Transp. Res. Part A Policy Pract. 2019, 127, 86-98. [CrossRef]

78. Westin, J.; Kågeson, P. Can high-speed rail offset its embedded emissions? Transp. Res. Part D Transp. Environ. 2012, $17,1-7$. [CrossRef]

79. Delaplace, M.; Dobruszkes, F. From low-cost airlines to low-cost high-speed rail? The French case. Transp. Policy 2015, 38, 73-85. [CrossRef]

80. Vickerman, R. Can high-speed rail have a transformative effect on the economy? Transp. Policy 2018, 62, 31-37. [CrossRef]

81. Moyano, A.; Martínez, H.S.; Coronado, J.M. From network to services: A comparative accessibility analysis of the Spanish high-speed rail system. Transp. Policy 2018, 63, 51-60. [CrossRef]

82. Dai, X.; Xu, M.; Wang, N. The industrial impact of the Beijing-Shanghai high-speed rail. Travel Behav. Soc. 2018, 12, 23-29. [CrossRef]

83. Kim, H.; Sultana, S.; Weber, J. A geographic assessment of the economic development impact of Korean high-speed rail stations. Transp. Policy 2018, 66, 127-137. [CrossRef]

84. Chen, X.; Liu, Y. Visualization analysis of high-speed railway research based on CiteSpace. Transp. Policy 2020, 85, 1-17. [CrossRef]

85. Levinson, D.M. Accessibility impacts of high-speed rail. J. Transp. Geogr. 2012, 22, 288-291. [CrossRef]

86. Weng, J.; Zhu, X.; Li, X. Impact of High-speed Rail on Destination Accessibility: A Case Study of China. J. China Tour. Res. 2020, 16, 494-509. [CrossRef]

87. Chinowsky, P.; Helman, J.; Gulati, S.; Neumann, J.; Martinich, J. Impacts of climate change on operation of the US rail network. Transp. Policy 2019, 75, 183-191.

88. Wang, D.-G.; Niu, Y.; Qian, J. Evolution and optimization of China's urban tourism spatial structure: A high-speed rail perspective. Tour. Manag. 2018, 64, 218-232.

89. Andrés, M.; Ortega, E.; López, E. Efficiency and spatial equity impacts of high-speed rail extensions in urban areas. Cities 2013, $30,18-30$.

90. Jin, C.; Xu, J.; Lu, Y.; Huang, Z. The impact of Chinese Shanghai-Nanjing high-speed rail on regional accessibility. Geogr. Tidsskr.-Dan. J. Geogr. 2013, 113, 133-145. 
91. Kaczensky, P.; Knauer, F.; Krze, B.; Jonozovic, M.; Adamic, M.; Gossow, H. The impact of high-speed, high volume traffic axes on brown bears in Slovenia. Biol. Conserv. 2003, 111, 191-204. [CrossRef]

92. Liu, L.; Zhang, M. High-speed rail impacts on travel times, accessibility, and economic productivity: A benchmarking analysis in city-cluster regions of China. J. Transp. Geogr. 2018, 73, 25-40.

93. Kamga, C.; Yazici, M.A. Achieving environmental sustainability beyond technological improvements: Potential role of high-speed rail in the United States of America. Transp. Res. Part D Transp. Environ. 2014, 31, 148-164. [CrossRef]

94. Matute, J.M.; Chester, M.V. Cost-effectiveness of reductions in greenhouse gas emissions from High-Speed Rail and urban transportation projects in California. Transp. Res. Part D Transp. Environ. 2015, 40, 104-113. [CrossRef]

95. Weea, B.v.; Brinkb, R.v.d.; Nijland, H. Environmental impacts of high-speed rail links in cost-benefit analyses: A case study of the Dutch Zuider Zee line. Transp. Res. Part D 2003, 8, 299-314.

96. Bukovac, S.; Douglas, I. The potential impact of High-Speed Rail development on Australian aviation. J. Air Transp. Manag. 2019, 78, 164-174. [CrossRef]

97. Long, Y.; Zhang, W. Prioritizing future funding and construction of the planned high-speed rail corridors of China-According to regional structure and urban land development potential indices. Transp. Policy 2019, 81, 381-395.

98. Raturi, V.; Verma, A. Analyzing competition between High-Speed Rail and Bus mode using market entry game analysis. Transp. Res. Procedia 2017, 25, 2373-2384.

99. Raturi, V.; Verma, A. A game-theoretic approach to analyze inter-modal competition between high-speed rail and airlines in the Indian context. Transp. Plan. Technol. 2019, 43, 20-47. [CrossRef]

100. Jiao, J.; Wang, J.; Jin, F. Impacts of high-speed rail lines on the city network in China. J. Transp. Geogr. 2017, 60, 257-266. [CrossRef]

101. Clauzel, C.; Girardet, X.; Foltête, J.-C. Impact assessment of a high-speed railway line on species distribution: Application to the European tree frog (Hyla arborea) in Franche-Comté. J. Environ. Manag. 2013, 127, 125-134.

102. Xu, W.; Zhou, J.; Yang, L.; Li, L. The implications of high-speed rail for Chinese cities: Connectivity and accessibility. Transp. Res. Part A Policy Pract. 2018, 116, 308-326.

103. Wang, B.; Loo, B.P.Y. Travel time use and its impact on high-speed-railway passengers' travel satisfaction in the e-society. Int. J. Sustain. Transp. 2019, 13, 197-209. [CrossRef]

104. Li, L.S.; Yang, F.X.; Cui, C. High-speed rail and tourism in China: An urban agglomeration perspective. Int. J. Tour. Res. 2019, 21, 45-60. [CrossRef]

105. Dalkic, G.; Balaban, O.; Tuydes-Yaman, H.; Celikkol-Kocak, T. An assessment of the $\mathrm{CO}_{2}$ emissions reduction in high-speed rail lines: Two case studies from Turkey. J. Clean. Prod. 2017, 165, 746-761.

106. Post, W. High-Speed Rail Lines by Country. Available online: https:/ /www.washingtonpost.com/wp-srv/world/highspeedrail. html?tid=grpromo (accessed on 11 July 2020).

107. Alberico, U. Director. The "Direttissima" Rome-Florence Railway Line (1983)_YouTube. Film. Available online: https: / / www.youtube.com/watch? $v=$ Wo35fZAe65g\&t=8s (accessed on 12 September 2020).

108. Railway-Technology. High Speed 2 (HS2) Railway, UK-Railway Technology. Available online: https:/ / www.railway-technolo gy.com/projects/high-speed-2-hs2/ (accessed on 12 September 2020).

109. Railway-Technology. Germany InterCity Express High-Speed Rail Network Operated by Deutsche Bahn-Railway Technology. Available online: https://www.railway-technology.com/projects/ice-high-speed-rail/ (accessed on 12 September 2020).

110. China High-Speed Rail Evolution: A Timeline of the Evolution. Available online: https://www.railway-technology.com/feature s/china-high-speed-rail-evolution/ (accessed on 11 July 2020).

111. Railway-Technology. Norway Tilt Trains Operated by Norwegian State Railways-Railway Technology. Available online: https:/ / www.railway-technology.com/projects/norway/ (accessed on 12 September 2020).

112. Railway-Technology. TGV South Korea High-Speed Rail Route Operated by Korail—Railway Technology. Available online: https:/ / www.railway-technology.com/projects/koreatgv / (accessed on 12 September 2020).

113. Bullet Train: Everything You Wanted to Know about Bullet Trains-What Is a High-Speed Railway? The Economic Times. Available online: https: / / economictimes.indiatimes.com/industry/transportation/railways/everything-you-wanted-to-kno w-about-bullet-trains/what-is-a-high-speed-railway/slideshow/60731138.cms (accessed on 11 July 2020).

114. Map of American High-Speed Rail Network—Business Insider. Available online: https:/ /www.businessinsider.com/map-of-a merican-high-speed-rail-network-2013-2 (accessed on 11 July 2020).

115. Chan, Y.; Fowe, J.A.; Arani, M. Routing in a Stochastic Network with Nonrecurrent Incidents: Behavioral Interpretation of Dynamic Traffic Assignment. ASCE-ASME J. Risk Uncertain. Eng. Syst. Part A Civil Eng. 2020, 6, 04020002. [CrossRef]

116. Tutton, M. How Green Is High-Speed Rail?-CNN. Available online: https://www.cnn.com/2011/11/18/world/how-green-ishsr/index.html (accessed on 19 November 2011).

117. Ohnsman, A. High-Speed LA-to-Las Vegas Virgin Train Wins $\$ 600$ Million California Bond Allocation. Available online: https:/ / www.forbes.com/sites/alanohnsman/2020/04/14/high-speed-la-to-las-vegas-virgin-train-wins-600-million-califor nia-bond-allocation/\#4c29ef6594f6 (accessed on 14 April 2020).

118. Kendall, A.; Chang, B. Life cycle greenhouse gas assessment of infrastructure construction for California's high-speed rail system. Transp. Res. Part D Transp. Environ. 2011, 16, 429-434.

119. Wang, D.; Qian, J.; Chen, T.; Zhao, M.; Zhang, Y. Influence of the High-Speed Rail on the Spatial Pattern of Regional TourismTaken Beijing-Shanghai High-Speed Rail of China as Example. Asia Pac. J. Tour. Res. 2014, 19, 890-912. 
120. Jones, H.; Moura, F.; Domingos, T. Life cycle assessment of high-speed rail: A case study in Portugal. Int. J. Life Cycle Assess. 2017, 22, 410-422. [CrossRef]

121. Llorca, C.; Ji, J.; Molloy, J.; Moeckel, R. The usage of location-based big data and trip planning services for the estimation of a long-distance travel demand model. Predicting the impacts of a new high-speed rail corridor. Res. Transp. Econ. 2018, 72, 27-36. [CrossRef]

122. Millard-Ball, A.; Schipper, L. Are We Reaching Peak Travel? Trends in Passenger Transport in Eight Industrialized Countries. Transp. Rev. 2011, 31, 358-378. [CrossRef]

123. Xu, B.; Cui, P.; Xu, H.; Chen, H.; Lin, Y. Commuter exposure to particle matter and carbon dioxide inside high-speed rail carriages. Transp. Res. Part D Transp. Environ. 2013, 20,1-6.

124. Zhang, Q.; Yang, H.; Wang, Q.; Zhang, A.; Zhang, Y. Impact of high-speed rail on market concentration and Lerner index in China's airline market. J. Air Transp. Manag. 2020, 83, 101755. [CrossRef]

125. Fengjun, J.; Jingjuan, J.; Yuanjing, Q.; Yu, Y. Evolution and geographic effects of high-speed rail in East Asia: An accessibility approach. J. Geogr. Sci. 2017, 27, 515-532.

126. Yin, P.; Lin, Z.; Prideaux, B. The impact of the high-speed railway on tourism spatial structures between two adjoining metropolitan cities in China: Beijing and Tianjin. J. Transp. Geogr. 2019, 80, 102495. [CrossRef] [PubMed]

127. Zhao, J.; Zhao, Y.; Li, Y. The variation in the value of travel-time savings and the dilemma of high-speed rail in China. Transp. Res. Part A Policy Pract. 2015, 82, 130-140. [CrossRef]

128. Sperry, B.R.; Burris, M.; Woosnam, K.M. Investigating the impact of high-speed rail equipment visualization on mode choice models: Case study in central Texas. Case Stud. Transp. Policy 2017, 5, 560-572. [CrossRef]

129. Zhang, Q.; Yang, H.; Wang, Q. Impact of high-speed rail on China's Big Three airlines. Transp. Res. Part A Policy Pract. 2017, 98, 77-85. [CrossRef]

130. Shaw, S.-L.; Fang, Z.; Lu, S.; Tao, R. Impacts of high-speed rail on railroad network accessibility in China. J. Transp. Geogr. 2014, $40,112-122$.

131. Momenitabar, M.; Mattson, J. A Multi-Objective Meta-Heuristic Approach to Improve the Bus Transit Network: A Case Study of Fargo-Moorhead Area. Sustainability 2021, 13, 10885. [CrossRef]

132. Dehdari Ebrahimi, Z.; Bridgelall, R.; Momenitabar, M. Extending Micromobility Deployments: A Concept and Local Case Study. In Advances in Data Science and Information Engineering, Transactions on Computational Science and Computational Intelligence; Stahlbock, R., Weiss, G.M., Abou-Nasr, M., Yang, C.Y., Arabnia, H.R., Deligiannidis, L., Eds.; Springer: Cham, Switzerland. [CrossRef]

133. Cascetta, E.; Papola, A.; Pagliara, F.; Marzano, V. Analysis of mobility impacts of the high-speed Rome-Naples rail link using withinday dynamic mode service choice models. J. Transp. Geogr. 2011, 19, 635-643. [CrossRef] 